\title{
Toxoplasma gondii and Neospora caninum infections in South American camelids in Switzerland and assessment of serological tests for diagnosis
}

Walter Basso ${ }^{1 *+} \oplus$, Elena Sollberger ${ }^{1,2 \dagger}$, Gereon Schares ${ }^{3}$, Susanne Küker ${ }^{4}$, Flurin Ardüser ${ }^{2}$, Gaia Moore-Jones $^{5}$ and Patrik Zanolari

\begin{abstract}
Background: Little is known about the epidemiology of Toxoplasma gondii and Neospora caninum infections in alpacas (Vicugna pacos) and llamas (Lama glama) outside South America. The study aimed to estimate the seroprevalence of T. gondii and N. caninum infections in South American camelids (SAC) in Switzerland, to optimize serological tests for SAC and to identify risk factors, which may favour infection.

Methods: A total of 571 sera from 132 Swiss farms (374 alpacas and 197 llamas, mean 4.3 animals/farm) were obtained. Four commercial enzyme-linked immunosorbent assays (ELISA) for detecting antibodies against T. gondii (ID Screen ${ }^{\circledR}$ Toxoplasmosis Indirect (TOXO-MS)) or N. caninum (i.e. ID Screen ${ }^{\circledR}$ Neospora caninum Indirect Multi-species (NCS-MS); ID Screen ${ }^{\circledR}$ Neospora caninum Competition (NCC) and ID Screen ${ }^{\circledR}$ Neospora caninum Indirect (NCS)) were first assessed for their use on SAC comparing their results with those in immunoblot, and optimizing cut-offs. Subsequently, two kits (TOXO-MS and NCS-MS) were selected for seroprevalence estimation. Additionally, a risk factor analysis for infection was performed on 41 farms, which agreed to participate in a web-based survey.
\end{abstract}

Results: Three kits (TOXO-MS, NCS-MS and NCC) showed almost perfect agreement (kappa > 0.901) with immunoblot results when the cut-offs were optimized, and one kit (NCS) proved not to be useful for detecting N. caninum seropositive SAC. By TOXO-MS ELISA, 82.3\% (308/374) of the alpacas and 84.8\% (167/197) of the llamas were seropositive for T. gondii, and 131/132 (99.2\%) farms had seropositive animals. By NCS-MS ELISA, 3.5\% (13/374) of the alpacas and 2.5\% (5/197) of the llamas evidenced antibodies against N. caninum, and 9.1\% (12/132) of the farms had seropositive animals. The variables "age" and "female sex" were identified as risk factors for T. gondii infection and "absence of cats in the farm during the last two years" as a protective factor. No risk or protective factors for N. caninum infection could be identified.

Conclusions: This nationwide cross-sectional study demonstrated for the first time the presence of antibodies against T. gondii and N. caninum in the Swiss SAC population, highlighting a high seroprevalence for T. gondii, the presence of cats as a risk factor and suggesting that SAC meat might represent an additional infection source for humans.

Keywords: Alpaca, Vicugna pacos, Llama, Lama glama, ELISA, Immunoblot, Toxoplasmosis, Neosporosis

\footnotetext{
*Correspondence: walter.basso@vetsuisse.unibe.ch

†Walter Basso and Elena Sollberger contributed equally to this work

${ }^{1}$ Institute of Parasitology, Vetsuisse-Faculty, University of Bern,

Länggassstrasse 122, 3012 Bern, Switzerland

Full list of author information is available at the end of the article
}

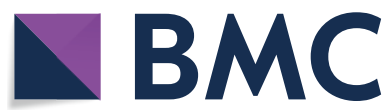

c The Author(s) 2020. This article is licensed under a Creative Commons Attribution 4.0 International License, which permits use, sharing, adaptation, distribution and reproduction in any medium or format, as long as you give appropriate credit to the original author(s) and the source, provide a link to the Creative Commons licence, and indicate if changes were made. The images or other third party material in this article are included in the article's Creative Commons licence, unless indicated otherwise in a credit line to the material. If material is not included in the article's Creative Commons licence and your intended use is not permitted by statutory regulation or exceeds the permitted use, you will need to obtain permission directly from the copyright holder. To view a copy of this licence, visit http://creativeco mmons.org/licenses/by/4.0/. The Creative Commons Public Domain Dedication waiver (http://creativecommons.org/publicdomain/ zero/1.0/) applies to the data made available in this article, unless otherwise stated in a credit line to the data. 


\section{Background}

Toxoplasma gondii and Neospora caninum (Apicomplexa: Sarcocystidae) are worldwide distributed cystforming coccidian parasites, which represent important causes of abortion and congenital infections in ruminants [1, 2]. Both parasites have heteroxenous lifecycles, with sexual development and oocyst production in the intestine of the definitive hosts and asexual development in extraintestinal tissues of the intermediate hosts. Only felids are natural definitive hosts for T. gondii [1] and only domestic dogs, dingoes, coyotes and wolves have been identified as definitive hosts for $N$. caninum so far [2]. Whereas cattle and other ruminants are the main intermediate hosts of $N$. caninum, all warm-blooded species (birds and mammals, including humans) are potential intermediate hosts of T. gondii $[1,2]$. Ruminants may become infected with these protozoan parasites either horizontally through ingestion of oocysts shed by the definitive hosts with the faeces, or vertically by transplacental parasite transmission from the dam to the foetus [1,2]. Carnivorous and omnivorous animals can also become infected through consumption of tissues from infected hosts containing cyst stages [3].

Infections with both parasites were described in numerous domestic and wild animal species, with variable clinical manifestations. Toxoplasma gondii infections are frequently asymptomatic but they may be associated with fatal disease in some hosts, including humans. Certain animal species such as Pallas' cats [4], meerkats [5], Australian marsupials [6,7] and New World primates [8] are highly susceptible to clinical toxoplasmosis and can develop fatal generalized infections. Additionally, $T$. gondii is considered one of the most important causes of abortion in small ruminants $[9,10]$, but noteworthy, it has no epidemiological significance as an abortifacient agent in cattle [1]. In humans, toxoplasmosis is considered one of the most common zoonoses worldwide and can cause serious illness especially after congenital infections or in immunosuppressed patients [1, 11]. Primary T. gondii infections in women during pregnancy may be associated with prenatal infection and severe damage to the foetus (including hydrocephalus, intracerebral calcifications, mental retardation, chorioretinitis and death). In immunosuppressed patients, chronic infections can be reactivated leading to encephalitis or generalized toxoplasmosis $[1,11]$. In recent years, $T$. gondii infections were also regarded as common cause of ocular disease in postnatal infections both in immunosuppressed and immunocompetent individuals [12]. In contrast to T. gondii, N. caninum has no zoonotic character but it is regarded as one of the major causes of abortion in cattle worldwide [2]; besides, it can also cause reproductive failure (i.e. abortion, stillbirths and perinatal mortality) in other ruminant species such as goats [13-15], sheep [16] and deer [17]. Furthermore, it represents an important cause of neuromuscular disease and death in dogs $[2,13$, 17].

Little is known about the meaning of toxoplasmosis and neosporosis in South American camelids (SAC) outside South America. Only few studies worldwide showed that T. gondii and N. caninum infections may occur in SAC (Tables 1 and 2), and that these infections may be occasionally associated with abortions [18-20] as well as with fatal generalized infection [21].

South American camelids are of great economic importance in the Andean Region of South America, where they are mainly bred for meat and fibre and reproductive problems may impair their breeding, causing significant economic losses [18]. Moreover, meat from infected SAC may be a potential infection source of $T$. gondii for humans, as it is often consumed undercooked. In Europe, the popularity and interest for SAC has shown a notable increase in the last years. Llamas (Lama glama) and alpacas (Vicugna pacos) are bred not only for fibre and meat production, but also for other purposes such as landscape maintenance, trekking, animal-assisted activities and therapy and also as companion animals [22, 23]. Llamas have also been used as guard animals in sheep herds against predation by lynxes in Switzerland [22] and coyotes in the USA [24] due to their natural aggressive behaviour against these animals. While at the beginning of year 2000 a total population of only 1622 SAC (623 alpacas and 999 llamas) and 257 breeders were registered in Switzerland [22], current records from the Swiss Federal Office for Statistics, revealed a total of 6739 SAC (3759 alpacas and 2980 llamas) in 2018, and a further significant increase $(+1.3 \%)$ in the alpaca population was estimated for 2019 [25]. This new situation represents a challenge for many veterinary practitioners in Europe, which are not familiar with the special management and sanitary requirements of these animal species. Although SAC share some viral, bacterial and parasitic agents with domestic and wild ruminants, the clinical significance and management of the infections might be different $[22,26]$. For example, while Dicrocoelium spp. infections are generally subclinical in cattle and small ruminants, they can cause severe liver lesions and fatal disease in SAC [26-28]. Moreover, SAC-specific nematodes (e.g. Graphinema auchenia, Spiculopteragia peruviana, Nematodirus lamae, Lamanema chavezi and Camelostrongylus spp.) are not common in Europe, and llamas and alpacas are frequently infected with nematodes from other ruminant species, but the strategies 
Table 1 Seroprevalence of T. gondii antibodies in South American camelids

\begin{tabular}{|c|c|c|c|c|c|c|}
\hline Country (Region) & SAC species & Test (commercial provider) & Cut-off & $\begin{array}{l}\text { No. positive/ } \\
\text { No. } \\
\text { examined }\end{array}$ & \% Positive & Reference \\
\hline \multirow[t]{2}{*}{ Peru (Lampa, Puno) } & Alpaca & IHA (Toxotest, Wiener Lab.) & $1: 16$ & $89 / 200$ & 44.5 & {$[48]$} \\
\hline & Llama & & & $38 / 136$ & 27.9 & \\
\hline Peru (Canchis, Cusco) & Alpaca & IFAT & $1: 50$ & $97 / 272$ & 35.7 & [49] \\
\hline \multirow[t]{2}{*}{$\begin{array}{l}\text { Peru (Peruvian Andes, Central and } \\
\text { South Sierra) }\end{array}$} & Llama & $\begin{array}{l}\text { IFAT } \\
\text { Conjugate: anti-llama IgG-FITC (VMRD) } \\
\text { + confirmation of positive results by } \\
\text { Western blot }\end{array}$ & $1: 50$ & $19 / 43$ & 44.2 & [69] \\
\hline & Vicuna & & & $11 / 200$ & 5.5 & \\
\hline \multirow[t]{3}{*}{ Peru (Puno, South-Eastern Peru) } & Alpaca & Immunoblot T.gondii & & $20 / 675$ & 3.0 & {$[30]$} \\
\hline & Llama & & & $7 / 81$ & 8.6 & \\
\hline & Vicuna & & & $3 / 114$ & 2.6 & \\
\hline Peru (Central Sierra) & Alpaca & IHA (Toxotest, Wiener Lab.). & $1: 16$ & $42 / 200$ & 21.0 & {$[50]$} \\
\hline Peru (Central Sierra) & Alpaca & $\begin{array}{l}\text { IFAT } \\
\text { Conjugate: anti-llama IgG-FITC (VMRD) }\end{array}$ & $1: 200$ & $22 / 258$ & 8.5 & {$[70]$} \\
\hline Peru (Melgar, Puno) & Llama & IFAT & $1: 200$ & $16 / 107$ & 14.9 & [71] \\
\hline \multirow{2}{*}{$\begin{array}{l}\text { Peru (Central and South Peruvian } \\
\text { Andes) }\end{array}$} & Alpaca & IFAT & $1: 200$ & $706 / 2874$ & 24.6 & {$[57]$} \\
\hline & Llama & Conjugate: anti-llama lgG FITC (VMRD) & & $460 / 1845$ & 24.9 & \\
\hline Argentina (Jujuy) & Llama & $\begin{array}{l}\text { IFAT } \\
\text { Conjugate: anti bovine IgG FITC } \\
\text { (Sigma-Aldrich) }\end{array}$ & $1: 50$ & $44 / 308$ & 14.3 & {$[37]$} \\
\hline Chile & Alpaca & IHA (in-house) & $1: 16$ & $32 / 447$ & 7.2 & {$[38]$} \\
\hline \multirow[t]{2}{*}{ Chile } & Alpaca & MAT & $1: 25$ & $15 / 127$ & 11.8 & {$[39]$} \\
\hline & Llama & & & $49 / 113$ & 43.3 & \\
\hline $\begin{array}{l}\text { USA (Northwest: Oregon, Washington } \\
\text { State and Idaho) }\end{array}$ & Llama & MAT & $1: 25$ & $95 / 283$ & 33.5 & [41] \\
\hline USA Virginia & Alpaca & MAT & $1: 25$ & $6 / 16$ & 37.5 & {$[40]$} \\
\hline \multirow[t]{2}{*}{ Germany (Hesse) } & Alpaca & Immunoblot T.gondii & & $4 / 12$ & 33.3 & {$[30]$} \\
\hline & Llama & & & $10 / 20$ & 50.0 & \\
\hline \multirow[t]{4}{*}{ Czech Republic } & Alpaca & $\begin{array}{l}\text { ELISA (ID Screen Toxoplasmosis indirect } \\
\text { multispecies ID.vet) }\end{array}$ & $S / P(\%) \geq 50 \%^{a}$ & $1 / 1$ & 100 & {$[42]$} \\
\hline & Llama & & & $7 / 8$ & 88.0 & \\
\hline & Alpaca & $\begin{array}{l}\text { IFAT } \\
\text { Conjugate: anti-llama IgG FITC (VMRD) }\end{array}$ & $1: 50$ & $0 / 1$ & 0 & \\
\hline & Llama & & & $4 / 8$ & 50.0 & \\
\hline
\end{tabular}

a $\mathrm{S} / \mathrm{P}(\%)$ calculated according to the formula: $\mathrm{S} / \mathrm{P} \%=(\mathrm{OD}$ sample/OD positive control $) \times 100, \mathrm{OD}$ optical density

Abbreviations: cELISA, competitive-inhibition enzyme-linked immunosorbent assay; IFAT, indirect fluorescent antibody test; FITC, fluorescein isothiocyanate conjugate; IHA, indirect hemagglutination; MAT, modified agglutination test

used for controlling parasites in cattle and small ruminants cannot be always directly extrapolated to SAC due to differences in pharmacokinetics, safety and efficacy for most antiparasitic drugs [26]. Therefore, a better understanding of the epidemiology and management of infectious and parasitic diseases of SAC in Europe is required.

The aims of this study were (i) to estimate the occurrence, distribution and importance of $T$. gondii and $N$. caninum infections in SAC in Switzerland, (ii) to optimize serological tests for this purpose, and (iii) to identify risk factors, which may favour T. gondii and $N$. caninum infections in these animal species.

\section{Methods}

\section{Field samples from South American camelids and farm data}

In order to estimate the nationwide seroprevalence of $T$. gondii and $N$. caninum infections in alpacas and llamas in Switzerland, a cross-sectional study including all 26 Swiss cantons was conducted. Registered SAC breeders were contacted by phone and invited to participate in the study. Each participating farm was visited, and blood samples from randomly selected animals (mean 4.3 sampled animals/farm) were obtained from the vena jugularis. Subsequently, serum was extracted and conserved 
Table 2 Seroprevalence of N. caninum antibodies in South American camelids

\begin{tabular}{|c|c|c|c|c|c|c|}
\hline $\begin{array}{l}\text { Country } \\
\text { Region }\end{array}$ & SAC species & Test (commercial provider) & Cut-off & $\begin{array}{l}\text { No. positives/ } \\
\text { No. examined }\end{array}$ & $\%$ Positives & Reference \\
\hline \multirow[t]{2}{*}{$\begin{array}{l}\text { Peru } \\
\text { Highlands, Central and Southern Peru }\end{array}$} & Alpaca & $\begin{array}{l}\text { IFAT } \\
\text { conjugate: anti-llama IgG FITC (VMRD) }\end{array}$ & $1: 50$ & $39 / 92$ & 42.4 & {$[58]$} \\
\hline & Llama & & $1: 50$ & $39 / 212$ & 18.4 & \\
\hline \multirow[t]{2}{*}{$\begin{array}{l}\text { Peru } \\
\text { Highlands, different regions }\end{array}$} & Alpaca & $\begin{array}{l}\text { IFAT } \\
\text { conjugate: anti-llama lgG-FITC (VMRD) } \\
\quad+\text { confirmation of positive results by } \\
\text { Westernblot }\end{array}$ & $1: 50$ & $14 / 78$ & 17.9 & [59] \\
\hline & Llama & & & $17 / 73$ & 23.3 & \\
\hline \multirow{3}{*}{$\begin{array}{l}\text { Peru } \\
\text { Puno, South-Eastern Peru }\end{array}$} & Alpaca & Immunoblot N. caninum & & $17 / 675$ & 2.5 & {$[30]$} \\
\hline & Llama & & & $1 / 81$ & 1.2 & \\
\hline & Vicuna & & & $0 / 114$ & 0 & \\
\hline $\begin{array}{l}\text { Peru } \\
\text { Yauli, Central Sierra }\end{array}$ & Alpaca & $\begin{array}{l}\text { IFAT } \\
\text { conjugate: anti-Ilama IgG FITC (VMRD) }\end{array}$ & $1: 100$ & $5 / 175$ & 2.9 & {$[72]$} \\
\hline \multirow[t]{2}{*}{$\begin{array}{l}\text { Peru } \\
\text { Central and South Peruvian Andes }\end{array}$} & Alpaca & $\begin{array}{l}\text { IFAT } \\
\text { conjugate: anti-Ilama IgG FITC (VMRD) }\end{array}$ & 1:100 & $425 / 2874$ & 14.8 & {$[57]$} \\
\hline & Llama & & & $153 / 1845$ & 8.3 & \\
\hline \multirow[t]{3}{*}{$\begin{array}{l}\text { Peru } \\
\text { Arequipa, South Peruvian Andes }\end{array}$} & Vicuna & $\begin{array}{l}\text { ELISA, Chekit Neospora - cELISA (IDEXX) } \\
+ \text { confirmation of positive results by } \\
\text { Westernblot }\end{array}$ & & $2 / 207$ & 1.0 & [73] \\
\hline & Alpaca & & & $2 / 571$ & 0.3 & \\
\hline & Llama & & & $0 / 43$ & 0 & \\
\hline $\begin{array}{l}\text { Peru } \\
\text { Huancavelica }\end{array}$ & Llama & $\begin{array}{l}\text { IFAT } \\
\text { conjugate: anti-Ilama IgG FITC (VMRD) }\end{array}$ & 1:100 & $12 / 98$ & 12.2 & [56] \\
\hline $\begin{array}{l}\text { Peru } \\
\text { Huancavelica }\end{array}$ & Alpaca & IFAT & 1:100 & $47 / 288$ & 16.3 & {$[55]$} \\
\hline $\begin{array}{l}\text { Argentina } \\
\text { Jujuy }\end{array}$ & Llama & $\begin{array}{l}\text { IFAT } \\
\text { conjugate: anti bovine lgG FITC (Sigma) }\end{array}$ & $1: 50$ & $3 / 308$ & 1.0 & {$[37]$} \\
\hline $\begin{array}{l}\text { Australia } \\
\text { South }\end{array}$ & Alpaca & $\begin{array}{l}\text { ELISA, N. caninum Antibody Test Kit ELISA } \\
\text { (IDEXX) + Protein G conjugate (Zymed } \\
\text { Recombinant Protein G HRP Conjugate, } \\
\text { Invitrogen) }\end{array}$ & & 0/182 & 0 & [53] \\
\hline $\begin{array}{l}\text { Australia } \\
\text { New South Wales and Victoria }\end{array}$ & Alpaca & $\begin{array}{l}\text { ELISA, N. caninum Antibody Test Kit - cELISA } \\
\text { (VMRD) }\end{array}$ & $\% l \geq 30 \%^{a}$ & $3 / 100$ & 3.0 & {$[24]$} \\
\hline \multirow{2}{*}{$\begin{array}{l}\text { Germany } \\
\text { Hesse }\end{array}$} & Alpaca & Immunoblot N. caninum & & $0 / 12$ & 0 & {$[30]$} \\
\hline & Llama & & & $0 / 20$ & 0 & \\
\hline \multirow[t]{4}{*}{ Czech Republic } & Alpaca & $\begin{array}{l}\text { ELISA, N. caninum Antibody Test Kit - cELISA } \\
\text { (VMRD) }\end{array}$ & $\% l \geq 30 \%^{a}$ & $0 / 1$ & 0 & [42] \\
\hline & Llama & & & $1 / 8$ & 12.5 & \\
\hline & Alpaca & $\begin{array}{l}\text { IFAT } \\
\text { conjugate: anti-Ilama IgG FITC (VMRD) }\end{array}$ & $1: 50$ & $0 / 1$ & 0 & \\
\hline & Llama & & & $1 / 8$ & 12.5 & \\
\hline
\end{tabular}

CELISA: competitive-inhibition enzyme-linked immunosorbent assay, IFAT: indirect fluorescent antibody test; ${ }^{\text {a }} \%$ l (\% inhibition) calculated according the formula: $\%$ I $=100-(\mathrm{OD}$ sample $\times 100 /$ mean OD negative control), OD optical density, S/P (\%) calculated according to the formula: $\mathrm{S} / \mathrm{P}=(\mathrm{OD}$ sample/OD positive control) $\times 100$; FITC: fluorescein isothiocyanate conjugate

at $-20{ }^{\circ} \mathrm{C}$ until analysis. At sampling, data on the farm (owner, register No. and location) and sampled animals (species [alpaca/llama], age and sex) were collected.

A total of 571 serum samples (i.e. 374 alpacas and 197 llamas) from 132 farms distributed along all 26 Swiss cantons was obtained (Fig. 1). The collected samples represented $8.6 \%$ of the total SAC population $(n=6619)$ and $10.2 \%$ and $6.7 \%$ of the total alpaca and llama populations ( $n=3666$ and 2953, respectively) in Switzerland at the beginning of sampling, respectively [29].

In order to assess putative risk factors for exposure, a standardized web-based questionnaire was prepared in 




Fig. 1 Map of Switzerland showing the distribution of South American camelid (SAC) breeding farms $(n=132)$ sampled in the study (all dots) and the farms in which N. caninum seropositive SAC were detected (red dots)

three Swiss national languages (i.e. German, French and Italian) and subsequently sent to the participating farms via e-mail. The questionnaire contained general questions on the farm, animals (i.e. SAC species, breed, number of SAC in the farm, origin), management (i.e. type of water supply, type of feeding, feed storage, presence and number of cats and dogs (and especially of kittens and puppies $<6$ months-old) in the farm during the last two years, access of cats/dogs to the stables and pasture, problems with rodents, presence of other animal species) and occurrence of abortions. Answering of the questionnaire was voluntary for all participants. All collected data, as well as the subsequent evaluations were processed confidentially.

\section{Control sera}

In all serological tests, known $N$. caninum or $T$. gondii positive and negative control sera were included in addition to those provided with the kits.

For the evaluation of commercial $N$. caninum ELISAs and in-house $N$. caninum immunoblot, serial sera from two 1-year-old llamas, which had been intravenously (iv) inoculated either with $4.8 \times 10 \mathrm{E} 6$ cell culturederived $N$. caninum tachyzoites (Llama 1) or with $5 \times$ 10E4 Vero cells (Llama 2) on day 0 of the experiment were used as positive and negative controls, respectively [30]. Serum samples from both animals were collected at 12 time points between days 0 and 52 after inoculation. While Llama 1 seroconverted against $N$. caninum, Llama 2 remained seronegative throughout the observation period [30]. Serum samples of both llamas obtained on day 52 post-inoculation were used as internal positive and negative controls in all test runs, in addition to the controls provided by the manufacturer.

For the evaluation of a commercial $T$. gondii ELISA and in-house T. gondii immunoblot, control sera from a naturally infected llama (Llama 2) (this llama, used as negative control in the experimental inoculation with $N$. caninum was seropositive for T. gondii at all samplings), five naturally infected alpacas (Alpaca 1-5) and three seronegative alpacas (Alpaca 6-8), previously tested at the Friedrich-Loeffler-Institut (FLI), Germany, by immunoblot were used. In all test runs positive (Llama 2) and negative (Alpaca 8) internal control sera were included in addition to the controls provided by the manufacturer. 
Additionally, in $N$. caninum tests, serum from a calf, experimentally inoculated with $N$. caninum tachyzoites was used [31].

\section{Serological tests}

Since no validated serological tests for antibody detection against T. gondii or N. caninum in SAC were available, in the first phase of the study commercial ELISA kits were evaluated for their use in these animal species comparing their results with those of immunoblot tests.

\section{ELISA}

In a first step, two commercially available ELISA kits: ID Screen ${ }^{\circledR}$ Toxoplasmosis Indirect (TOXO-MS; for dogs, cats, goats, sheep, cattle and pigs; ID.vet, Grabels, France) and ID Screen ${ }^{\circledR}$ Neospora caninum Indirect Multi-species (NCS-MS; for dogs, goats, sheep and cattle; ID.vet) were used for screening according to the manufacturer's instructions. In both kits, multi-species conjugates were used as secondary antibodies.

For each serum, a sample-to-positive ratio ( $\mathrm{S} / \mathrm{P}$ ratio) was calculated based on the optical density (OD) of the sample and the positive and negative controls of the kit according to the formula $\mathrm{S} / \mathrm{P} \%=(\mathrm{OD}$ sample $-\mathrm{OD}$ negative control/ OD positive control - OD negative control) $\times 100$. According to the manufacturer, animals with $\mathrm{S} / \mathrm{P} \% \leq 40 \%$ are considered negative, inconclusive if $40 \%$ $<\mathrm{S} / \mathrm{P} \%>50 \%$ and positive if $\mathrm{S} / \mathrm{P} \% \geq 50 \%$. Since these kits are not validated for SAC, the ELISA cut-offs were later re-adjusted based on immunoblot results.

In order to assess if the results obtained with NCS-MS ELISA were comparable with those from other kits, in a second step, all sera tested for antibodies against $N$. caninum by both NCS-MS ELISA and $N$. caninum immunoblot were re-tested by two additional ELISA kits: (i) ID Screen ${ }^{\circledR}$ Neospora caninum Indirect (NCS; indirect ELISA for detection of antibodies against $N$. caninum in serum, plasma or milk from cattle, sheep or goats; ID.vet), which uses an anti-ruminant conjugate; and (ii) ID Screen ${ }^{\circledR}$ Neospora caninum Competition (NCC; competitive ELISA for detection of antibodies against $N$. caninum in serum or plasma from cattle, sheep, goats, dogs or other susceptible species; ID.vet). The cut-offs indicated by the manufacturer for NCS ELISA were the same ones as for NCS-MS ELISA. In the Competition ELISA, for each sample the competition percentage (S/N\%) was calculated according to the formula: $\mathrm{S} / \mathrm{N} \%=(\mathrm{OD}$ sample/ OD negative control) $\times 100$. The recommended cut-offs by the manufacturer were: $\mathrm{S} / \mathrm{N} \% \leq 50 \%$ : positive, doubtful if $50 \%<\mathrm{S} / \mathrm{N} \% \leq 60 \%$ and negative if $\mathrm{S} / \mathrm{N} \%>60 \%$. The
Competition ELISA was performed with the overnight incubation protocol, as described by the manufacturer.

\section{Immunoblot}

At the Institute of Parasitology, Vetsuisse Faculty Bern (IPB), in-house $T$. gondii tachyzoite surface antigen TgSAG1 (P30)-based and N. caninum tachyzoite-based immunoblots were performed to confirm ELISA results or to optimize the cut-offs of the commercial kits.

Pellets containing either $3 \mu \mathrm{g}$ of native affinity-purified T. gondii TgSAG1 antigen (TOXO P30 B-10 Antigen, SR2B: Société de Recherche et de Réalisations Biotechnologiques, Avrillé, France) or $2.6 \times 10 \mathrm{E} 7$ N. caninum tachyzoites were resuspended in $400 \mu \mathrm{l}$ sample buffer [32], incubated for $5 \mathrm{~min}$ at $95^{\circ} \mathrm{C}$ and $1000 \mathrm{rpm}$ in a Thermomixer compact (Eppendorf), and electrophoresed in two precast polyacrylamide gels (Criterion ${ }^{\mathrm{TM}}$ TGX StainFree $^{\mathrm{TM}} 4-20 \%$ precast gels for PAGE, Bio-Rad, Hercules, CA, USA) under non-reducing conditions along with a pre-stained protein standard (Precision Plus Protein ${ }^{\mathrm{TM}}$ Dual Extra Standards, Bio-Rad). Subsequently, the antigens were electrophoretically transferred to nitrocellulose membranes (Trans-Blot Turbo ${ }^{\mathrm{TM}}$, Bio-Rad), cut into stripes and blocked for $30 \mathrm{~min}$ with blocking solution (PBS with 0.05\% (v/v) Tween 20 (Sigma, Munich, Germany) and $2 \%(\mathrm{v} / \mathrm{v})$ fish gelatine (Serva Electrophoresis $\mathrm{GmbH}$, Heidelberg, Germany)). Selected serum samples (according to ELISA results) were tested at 1:100 dilution in blocking solution and incubated at room temperature for $60 \mathrm{~min}$. Afterwards, the stripes were washed 5 times during $5 \mathrm{~min}$ with $0.05 \%$ Tween 20-PBS solution. For detection of specific antibodies against $T$. gondii-SAG1 antigen or against $N$. caninum, the stripes were incubated with a rabbit anti-llama IgG $(\mathrm{H}+\mathrm{L})$ secondary antibody, HRP (Invitrogen, Thermo Fisher Scientific, Waltham, MA, USA) at 1:600 dilution in $0.05 \%$ Tween 20-PBS at room temperature for $60 \mathrm{~min}$. Washing was performed as indicated above and followed by a $15-20 \mathrm{~min}$ incubation step with substrate solution $\left(40 \mu \mathrm{H}_{2} \mathrm{O}_{2}(30 \%\right.$ (v/v) and $30 \mathrm{mg}$ 4-chloro-1-naphthol (Sigma-Aldrich) in $40 \mathrm{ml}$ PBS, 20\% (v/v) methanol). The reaction was stopped by addition of distilled water. For $T$. gondii, a serum reaction against the immunodominant antigen TgSAG1 visible as a sole band of a relative molecular mass of $30 \mathrm{kDa}$ was recorded as positive. For $N$. caninum, a serum was considered positive when reaction against at least two out of five $N$. caninum relevant immunodominant antigens (i.e. 17, $29,30,33$ and $37 \mathrm{kDa}$ ) were observed [30, 32]. If only one band was visible, the sample was considered inconclusive. 


\section{ROC-analysis and optimization of ELISA cut-offs for SAC}

The R software, version 3.5.3 [33] and the R package optimal.cutpoints were used to define optimal cut-offs for the commercial ELISA kits to detect antibodies against $T$. gondii (TOXO-MS) and N. caninum (NCS-MS and NCC) in SAC. For this, receiver operating characteristics (ROC) curve analysis was used, and relative to the immunoblot results the area under the ROC curve (AUC), diagnostic sensitivity, specificity, and positive and negative predictive values including 95\% confidence intervals (95\% CI) were determined. According to an arbitrary guideline, the area under the curve (AUC) was considered: non-informative (AUC $=0.5)$; low accurate $(0.5<$ AUC $\leq 0.7)$; moderately accurate $(0.7<\mathrm{AUC} \leq 0.9)$; highly accurate $(0.9<$ $\mathrm{AUC}<1)$; or perfect $(\mathrm{AUC}=1)$ [34].

To evaluate the agreement among different tests considering the ELISA cut-offs suggested by the manufacturer and the optimized cut-offs, an inter-rater agreement (kappa) was calculated [35] and kappa values (к) were considered as follows: slight agreement $(\kappa=0-0.20)$; fair agreement $(\kappa=0.21-0.40)$; moderate agreement $(\mathrm{\kappa}$ $=0.41-0.60)$; substantial agreement $(\kappa=0.61-0.80)$; or almost perfect agreement $(\mathrm{k}=0.81-1.00)$ [36].

\section{Risk factor analysis}

A risk factor analysis for T. gondii and N. caninum seropositivity was performed based on the information collected with the web-based questionnaire.

First, univariate models were performed considering the farm status ("seropositive" or "seronegative") as dependent variables and the potential risk factors included in the questionnaire as independent variables. One farm was considered "seropositive" for T. gondii or $N$. caninum when at least one of the tested animals in the farm gave a positive serological result for these parasites. All risk factors were tested as categorical variables with the Pearson's Chi-square test and the Likelihood Ratio. The null hypothesis (H0) aimed to prove the independence between the infection status and the corresponding risk factors (categorical variables).

Secondly, bivariable-multilevel-modelling (generalized linear mixed modelling fit by maximum likelihood (Laplace approximation)) was performed using R (http:// www.R-project.org) version 3.3.5, by applying the package lme4. Because individual animals clustered in farms, "farm" was included as a random effect variable. Because in T. gondii seropositivity increased with age, "age" (in months) of individual animals had to be regarded as an important risk or effect-modifying explanatory variable. Thus, data on age of the animals were included into each of the bivariable models calculated. Animals, for which no birth date was available were excluded from the analysis. The Akaike information criterion (AIC) was used to characterize the relative model quality. The serological status ("seropositive" or "seronegative") for $T$. gondii and $N$. caninum infections that were considered in the analyses were those obtained by TOXO-MS and NCS-MS ELISA, respectively, when the optimized cut-offs were used.

\section{Results}

\section{ID Screen ${ }^{\circledR}$ Toxoplasmosis indirect ELISA (TOXO-MS)}

Considering the thresholds suggested by the kit's manufacturer, 468/571, 4/571 and 99/571 of the tested animals showed a positive, inconclusive and negative result for $T$. gondii, respectively.

Llama 1, experimentally inoculated with $N$. caninum remained seronegative for $T$. gondii throughout the experimental period (ELISA $S / P$ values between 9.34-17.76\%). Llama 2, experimentally inoculated with Vero cells and used as a negative control for $N$. caninum, always showed ELISA S/P values above 100\% (106.41$129.12 \%)$ for $T$. gondii and was therefore considered as naturally infected with this parasite. All five known naturally infected alpacas (Alpaca 1-5) used as positive controls also gave positive results in the T. gondii ELISA (S/P 122.81-207.11\%). The two negative control alpacas

Table 3 Results of receiver operating chraracteristics (ROC) analysis

\begin{tabular}{lllllll}
\hline ELISA Kit & Optimized ELISA cut-off & $\begin{array}{l}\text { AUC } \\
(95 \% \mathrm{Cl})\end{array}$ & $\begin{array}{l}\text { \% Relative } \\
\text { sensitivity (95\% } \\
\text { Cl) }\end{array}$ & \% Relative specificity (95\% Cl) & PPV \% (95\% Cl) & NPV \% (95\% Cl) \\
\hline TOXO-MS & $\geq 36.2$ S/P\% & $0.97(0.94-1.00)$ & $94.5(87.6-98.2)$ & $97.9(92.6-99.7)$ & $97.7(92.0-99.3)$ & $94.9(88.5-99.4)$ \\
NCS-MS & $\geq 34.9$ S/P\% & $0.96(0.91-1.01)$ & $89.3(71.8-97.7)$ & $100.0(95.4-\mathrm{NaN})$ & $100(86.9-100)$ & $96.3(88.8-\mathrm{NaN})$ \\
NCC & $\leq 78.6$ S/N\% & $0.97(0.92-1.01)$ & $92.9(76.5-99.1)$ & $97.4(91.0-99.7)$ & $92.9(77.7-99.1)$ & $97.4(90.5-99.7)$ \\
\hline
\end{tabular}

Notes: Relative accuracies of commercial ELISA kits used for detection of antibodies against Toxoplasma gondii (i.e. ID Screen ${ }^{\circledR}$ Toxoplasmosis Indirect ELISA) and N. caninum (i.e. ID Screen ${ }^{\circledR}$ Neospora caninum Indirect Multi-species ELISA and ID Screen ${ }^{\circledR}$ Neospora caninum Competition ELISA) in South American camelids, in relation to $N$. caninum and T. gondii immunoblots

Abbreviations: TOXO-MS, ID Screen ${ }^{\circledR}$ Toxoplasmosis Indirect; NCS-MS, ID Screen ${ }^{\circledR}$ Neospora caninum Indirect Multi-species ELISA; NCC, ID Screen ${ }^{\circledR}$ Neospora caninum Competition; S/P\%, sample-to-positive ratio; S/N\%, competition percentage; AUC, area under the ROC curve; $\mathrm{Cl}$, confidence interval; TP, true positives; $\mathrm{FP}$, false positives; TN, true negatives; FN, false negatives; PPV, positive predictive value; NPV, negative predictive value; NaN, upper limit of the confidence interval could not be computed 


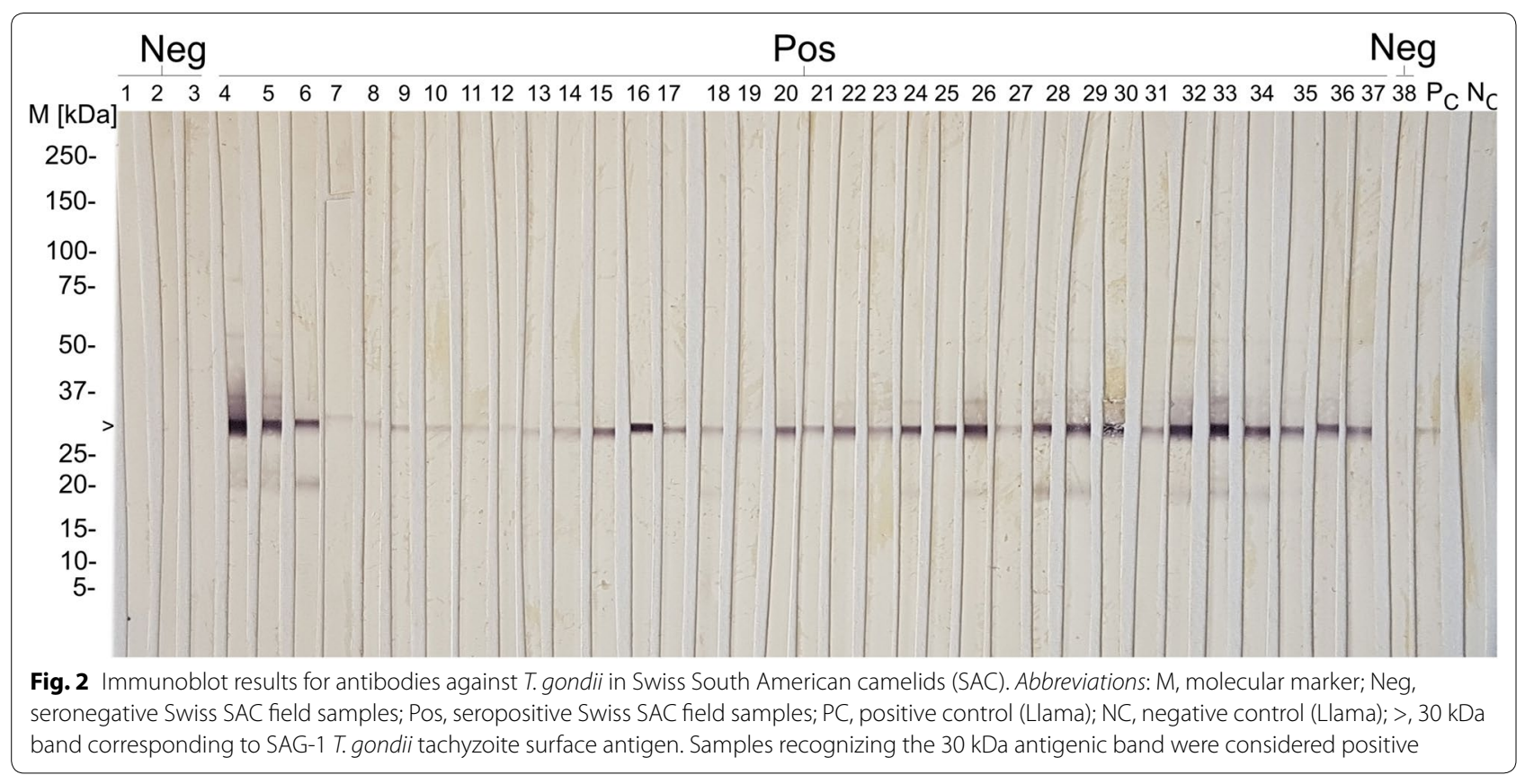

(Alpaca 6-8) tested also negative in the commercial ELISA with values well below the cut-off suggested by the manufacturer (S/P 4.1\%, 3.05\% and 10.08\%, respectively). When the cut-off was re-adjusted based on ROC analysis considering the immunoblot results (Table 3; i.e. cut-off $=\mathrm{S} / \mathrm{P} 36.2 \%$, relative sensitivity $=94.5 \%$, relative specificity $=97.9 \%$ ), the general seroprevalence at the animal level was $83.2 \%(475 / 571$, i.e. $82.3 \%(308 / 374)$ of the alpacas and $84.8 \%(167 / 197)$ of the llamas were seropositive for T. gondii) and the seroprevalence at the farm level was $99.2 \%(131 / 132)$. Only in one of the 132 participating farms all tested animals $(4 / 4)$ were seronegative for $T$. gondii.

\section{Toxoplasma gondii immunoblot}

All control animals $(n=9)$ and selected field serum samples $(n=177)$ based on the ELISA results using the manufacturer's cut-offs were tested by immunoblot, i.e. all negative samples ( $n=97$; S/P 1.70-39.13\%), all samples with inconclusive results $(n=4$; S/P 42.30-49.93\%) and all positive samples with $\mathrm{S} / \mathrm{P}$ values of $50.83-101.07 \%$ $(n=26)$, as well as five groups of five samples each, randomly selected within arbitrarily defined intervals (i.e. group 1: S/P 120.14-125.07\%; group 2: S/P 149.93152.30\%; group 3: S/P 170.74-172.33\%; group 4: S/P 190.29-191.09\%; group 5: S/P 220.00-221.70\%); and the 25 serum samples with the highest $\mathrm{S} / \mathrm{P}$ values $(\mathrm{S} / \mathrm{P}$ 247.04-284.23\%) (Fig. 2).

The T. gondii ELISA kit showed almost perfect agreement with immunoblot results (considering the manufacturer's cut-off, weighted $\mathrm{k}=0.887$; considering the optimized cut-off, $\mathrm{k}=0.925$ ) (Table 4). All but two $(86 / 88)$ of the selected animals with positive ELISA results and all four samples with inconclusive results yielded positive results in immunoblot. Eight out of 102 serum samples that were first considered negative in ELISA (S/P $<40 \%)$ showed a positive result in the immunoblot. The T. gondii naturally infected llama (Llama 2) and all five naturally infected alpacas (Alpaca 1-5) showed immunoblot positive reactions, and the negative control alpacas (Alpaca 6-8) were confirmed as seronegative.

\section{ID Screen ${ }^{\circledR}$ Neospora caninum indirect multi-species ELISA (NCS-MS)}

Considering the cut-offs proposed by the manufacturer for other animal species, 14/571, 3/571 and 554/571 out of the tested SAC field samples yielded a positive, inconclusive and negative result for $N$. caninum, respectively. Considering these cut-offs, the llama experimentally infected with $N$. caninum (Llama 1) showed inconclusive ELISA values between 19-23 dpi (S/P 43.45-49.66\%) and positive values $(\mathrm{S} / \mathrm{P} \geq 51.45 \%)$ from $26 \mathrm{dpi}$ until the end of the observation period ( $52 \mathrm{dpi}$ ). The negative control animal (Llama 2) showed S/P values below the cut-off (1.89-4.82\%) at all samplings (Fig. 3).

In order to adapt the kit for testing SAC, the ELISA cut-off was recalculated by a ROC-analysis based on the immunoblot results (Table 3). With an optimized cut-off (i.e. cut-off $=\mathrm{S} / \mathrm{P} 34.9 \%$, relative sensitivity $=89.3 \%$, relative specificity $=100 \%), 3.15 \%(18 / 571)$ of the sampled 
Table 4 Inter-rater agreement (Kappa value) between ELISA kits for detection of antibodies against T. gondii (ID Screen ${ }^{\circledR}$ Toxoplasmosis Indirect) or $N$. caninum (ID Screen ${ }^{\circledR}$ Neospora caninum indirect multi-species and ID Screen ${ }^{\circledR}$ Neospora caninum Competition) and immunoblot, and between ELISA kits (ID Screen ${ }^{\circledR}$ Neospora caninum Indirect Multi-species and ID Screen ${ }^{\circledR}$ Neospora caninum Competition)

\begin{tabular}{|c|c|c|c|c|c|c|c|c|c|c|}
\hline & & \multicolumn{4}{|c|}{ TOXO-MS (manufacturer's cut-offs) } & \multicolumn{4}{|c|}{ TOXO-MS (optimized cut-off) } & \\
\hline & & Positive & Doubtful & Negative & Total & Positive & Doubtful & Negative & Total & \\
\hline \multirow[t]{10}{*}{ T. gondii immunoblot } & Positive & 80 & 3 & 8 & 91 & 86 & 0 & 5 & 91 & \\
\hline & Doubtful & 0 & 0 & 0 & 0 & 0 & 0 & 0 & 0 & \\
\hline & Negative & 1 & 0 & 94 & 95 & 2 & 0 & 93 & 95 & \\
\hline & Total & 81 & 3 & 102 & 186 & 88 & 0 & 98 & 186 & \\
\hline & Kappa (к) & \multicolumn{4}{|l|}{0.873} & \multicolumn{5}{|l|}{0.925} \\
\hline & SE of $k$ & \multicolumn{4}{|l|}{0.035} & \multicolumn{5}{|l|}{0.028} \\
\hline & $95 \% \mathrm{Cl}$ & \multicolumn{4}{|l|}{$0.804-0.941$} & \multicolumn{5}{|l|}{$0.870-0.979$} \\
\hline & Weighted k & \multicolumn{4}{|l|}{0.887} & \multicolumn{5}{|l|}{0.925} \\
\hline & & \multicolumn{4}{|c|}{ NCS-MS (manufacturer's cut-offs) } & \multicolumn{4}{|c|}{ NCS-MS (optimized cut-off) } & \\
\hline & & Positive & Doubtful & Negative & Total & Positive & Doubtful & Negative & Total & \\
\hline \multirow[t]{10}{*}{ N. caninum immunoblot } & Positive & 19 & 5 & 4 & 28 & 25 & 0 & 3 & 28 & \\
\hline & Doubtful & 0 & 0 & 2 & 2 & 0 & 0 & 2 & 2 & \\
\hline & Negative & 0 & 0 & 76 & 76 & 0 & 0 & 76 & 76 & \\
\hline & Total & 19 & 5 & 82 & 106 & 25 & 0 & 81 & 106 & \\
\hline & Kappa (к) & \multicolumn{4}{|l|}{0.739} & \multicolumn{5}{|l|}{0.879} \\
\hline & SE of $k$ & \multicolumn{4}{|l|}{0.066} & \multicolumn{5}{|l|}{0.052} \\
\hline & $95 \% \mathrm{Cl}$ & \multicolumn{4}{|l|}{$0.610-0.868$} & \multicolumn{5}{|l|}{$0.777-0.981$} \\
\hline & Weighted k & \multicolumn{4}{|l|}{0.806} & \multicolumn{5}{|l|}{0.901} \\
\hline & & \multicolumn{4}{|c|}{ NCC (manufacturer's cut-offs) } & \multicolumn{4}{|c|}{ NCC (optimized cut-off) } & \\
\hline & & Positive & Doubtful & Negative & Total & Positive & Doubtful & Negative & Total & \\
\hline N. caninum immunoblot & Positive & 21 & 5 & 2 & 28 & 26 & 0 & 2 & 28 & \\
\hline & Doubtful & 1 & 1 & 0 & 2 & 2 & 0 & 0 & 2 & \\
\hline & Negative & 0 & 0 & 76 & 76 & 1 & 0 & 75 & 76 & \\
\hline & Total & 22 & 6 & 78 & 106 & 29 & 0 & 77 & 106 & \\
\hline & Kappa (к) & 0.819 & & & & 0.884 & & & & \\
\hline & SE of $k$ & 0.055 & & & & 0.049 & & & & \\
\hline & $95 \% \mathrm{Cl}$ & $0.710-0.927$ & & & & $0.788-0.980$ & & & & \\
\hline & Weighted k & 0.876 & & & & 0.905 & & & & \\
\hline & A & NCC (manufa & cturer's cut & -offs) & & B & NCC (optimiz & zed cut-off) & & \\
\hline & & Positive & Doubtful & Negative & Total & & Positive & Doubtful & Negative & Total \\
\hline NCS-MS (A: manufacturer's cut-off & Positive & 18 & 1 & 0 & 19 & & 26 & 0 & 0 & 26 \\
\hline B: optimized cut-off) & Doubtful & 3 & 2 & 0 & 5 & & 0 & 0 & 0 & 0 \\
\hline & Negative & 1 & 3 & 78 & 82 & & 3 & 0 & 77 & 80 \\
\hline & Total & 22 & 6 & 78 & 106 & & 29 & 0 & 77 & 106 \\
\hline & Kappa (к) & 0.807 & & & & & 0.926 & & & \\
\hline & SE of $k$ & 0.060 & & & & & 0.042 & & & \\
\hline & $95 \% \mathrm{Cl}$ & $0.689-0.925$ & & & & & $0.845-1.000$ & & & \\
\hline & Weighted k & 0.876 & & & & & 0.926 & & & \\
\hline
\end{tabular}



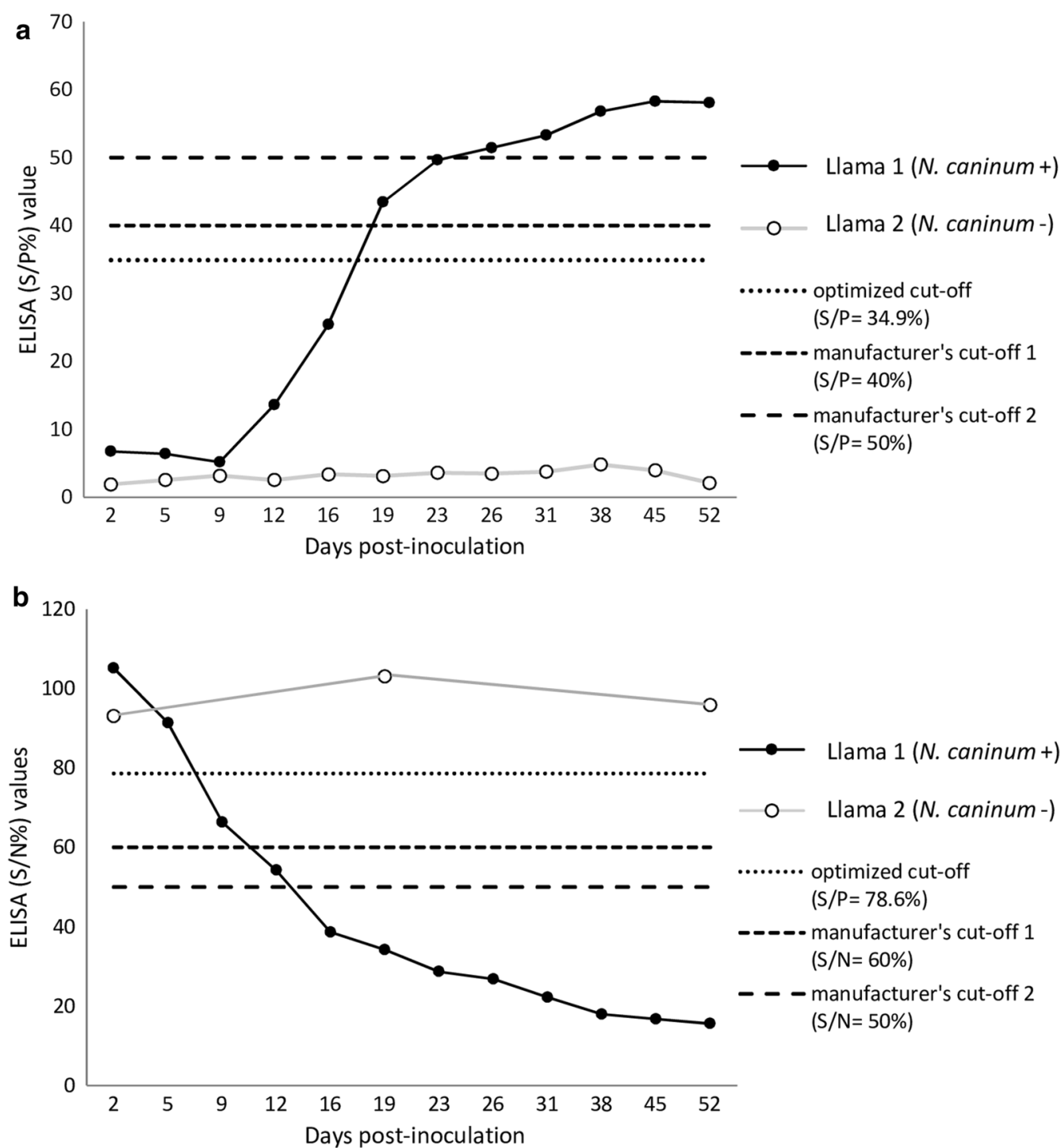

Fig. 3 ELISA results for antibodies against N. caninum on serum samples from a llama experimentally inoculated with $4.8 \times 10$ E6 cell culture-derived N. caninum tachyzoites (Llama 1) and from a control llama inoculated with $5 \times 10$ E4 Vero cells (Llama 2) [30]. a ID Screen ${ }^{\circledR}$ Neospora caninum indirect multi-species, S/P\% = sample-to-positive ratio, calculated based on the OD (optical density) of the sample and the positive and negative controls of the kit according to the formula $S / P \%=\left(O D_{\text {sample }}-O D_{\text {negative control }} / O D_{\text {positive control }}-O D_{\text {negative control }}\right) \times 100$. $\mathbf{b} \mid D S c r e e n{ }^{\circledR}$ Neospora caninum Competition, $\mathrm{S} / \mathrm{N} \%=$ competition percentage, calculated according to the formula: $\mathrm{S} / \mathrm{N} \%=\left(\mathrm{OD}_{\text {sample }} / \mathrm{OD}_{\text {negative control }}\right) \times 100$

SAC tested positive for $N$. caninum. According to the SAC species, the estimated seroprevalences in alpacas and llamas were $3.5 \%(13 / 374)$ and $2.5 \%(5 / 197)$, respectively, and the seroprevalence at the farm level was $9.1 \%$ (12/132). Considering the optimized ELISA cut-off, seroconversion of the experimentally infected llama could be already observed at 19 dpi. (Fig. 3).

The 18 seropositive animals for N. caninum in NCSMS ELISA were 13 alpacas and five llamas, 17 animals older than 36 months and one animal of unknown age, 13 females and five males, and derived from 12 different farms. In nine of the farms only one animal/ farm (i.e. five llamas and four alpacas) tested positive, and in three farms $4 / 5,3 / 4$ and $2 / 5$ of the tested alpacas were seropositive. The mean ELISA S/P values of the 18 seropositive animals was $76.4 \%$. All $N$. caninum seropositive animals were also T. gondii-seropositive.

\section{Neospora caninum immunoblot}

Selected field samples $(n=92)$ and the control animals (Llama 1 and 2) were tested by $N$. caninum immunoblot. Based on the results in the NCS-MS ELISA, all samples 


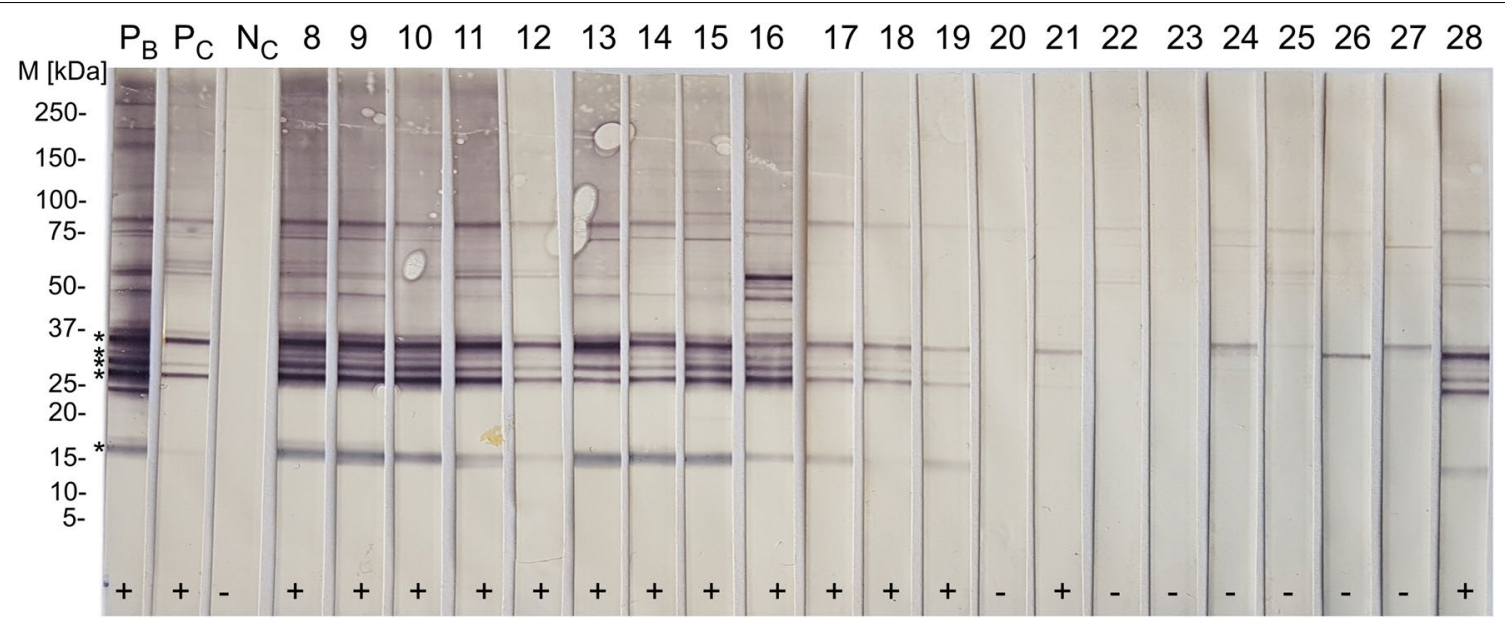

Fig. 4 Immunoblot results for antibodies against N. caninum on field serum samples from Swiss South American camelids (SAC). Abbreviations: M, marker; PB, positive control (bovine); PC, positive control (Llama 1); NC, negative control (Llama 2); samples 8-28, Swiss SAC field serum samples; +, positive immunoblot result; -, negative immunoblot result. Bands corresponding to immunodominant N. caninum antigens $(17,29,30,33$ and 37 $\mathrm{kDa}$ ) are indicated with *. Samples recognizing two or more immunodominant antigens were considered positive

with an $\mathrm{S} / \mathrm{P} \geq 9 \%(n=59)$ and further 33 randomly selected samples within the $\mathrm{S} / \mathrm{P}$ range $1-8.31 \%$ were further tested by immunoblot. All 14 animals, which were classified as positive using the cut-off recommended by the manufacturer, as well as the three animals classified as inconclusive, tested positive in immunoblot (Fig. 4). A further animal with $\mathrm{S} / \mathrm{P}$ value $34.9 \%$ yielded a clear positive result. An additional sample with S/P value of $14.15 \%$ in the ELISA also reacted against the immunodominant $N$. caninum antigens. This was a llama from a farm in which another $N$. caninum seropositive animal (by both ELISA and immunoblot) had been detected. Besides, also two alpacas from a same farm with ELISA S/P values of 5.39 and 9.99 were positive in the immunoblot.

The llama experimentally inoculated with $N$. caninum tachyzoites (Llama 1), showed reaction against the 29 $\mathrm{kDa}$ immunodominant antigen already at $12 \mathrm{dpi}$ (Fig. 5), and against two or more immunodominant $N$. caninum antigens $(17,29,30,33$ and $37 \mathrm{kDa})$ from $16 \mathrm{dpi}$. The $N$. caninum seronegative control animal (Llama 2) did not show any reaction against $N$. caninum antigens throughout the whole observation period (tested at 2, 19 and 52 dpi) (Fig. 5).

\section{ID Screen ${ }^{\circledR}$ Neospora caninum Competition ELISA (NCC)}

All sera tested by both NCS-MS ELISA and immunoblot were subsequently tested by NCC ELISA and the cut-off was optimized for SAC based on immunoblot results, as indicated above. By ROC analysis, a cut-off of S/N\% $\leq$ 78.6 was suggested (Table 3 ). With the optimized cut-off, NCC ELISA evidenced a relative sensitivity of $92.9 \%$ and a relative specificity of $97.4 \%$ respect to the $N$. caninum immunoblot, and an almost perfect agreement with immunoblot and NCS-MS results (Table 4). With the competitive ELISA (considering the optimized cut-off), seroconversion in Llama 1 (experimentally inoculated with $N$. caninum tachyzoites) could already be detected at $9 \mathrm{dpi}$, with positive ELISA values until the end of the study at $52 \mathrm{dpi}$. If the cut-offs suggested by the manufacturer were considered, seroconversion would have occurred $16 \mathrm{dpi}$, with doubtful values at $12 \mathrm{dpi}$ (Fig 3).

\section{ID Screen ${ }^{\circledR}$ Neospora caninum indirect ELISA (NCS)}

All analysed sera, including those from animals positive in N. caninum immunoblot and serial samples from the llama experimentally infected with $N$. caninum gave negative results (ELISA values similar to those from the negative controls) in NCS ELISA using an anti-ruminant conjugate.

\section{ROC-analysis and optimization of ELISA cut-offs for SAC}

The relative accuracies of NCS-MS, NCC and TOXO-MS ELISAs in relation to N. caninum and T. gondii immunoblots, respectively, are provided in Table 3 . The statistical analyses suggested a cut-off of S/P 34.9\% for NCS-MS, $78.6 \% \mathrm{~S} / \mathrm{N}$ for NCC, and $36.2 \% \mathrm{~S} / \mathrm{P}$ for TOXO-MS ELISA (Table 3). The inter-rater agreement (kappa value) between all three ELISAs and the respective immunoblots and between NCS-MS and NCC ELISA are provided in Table 4. The agreement of all three tested ELISAs with immunoblot was almost perfect, being higher when the adapted cut-offs were considered. Further, also the agreement between both $N$. caninum ELISAs (NCS-MS and NCC) was almost perfect (Table 4). 


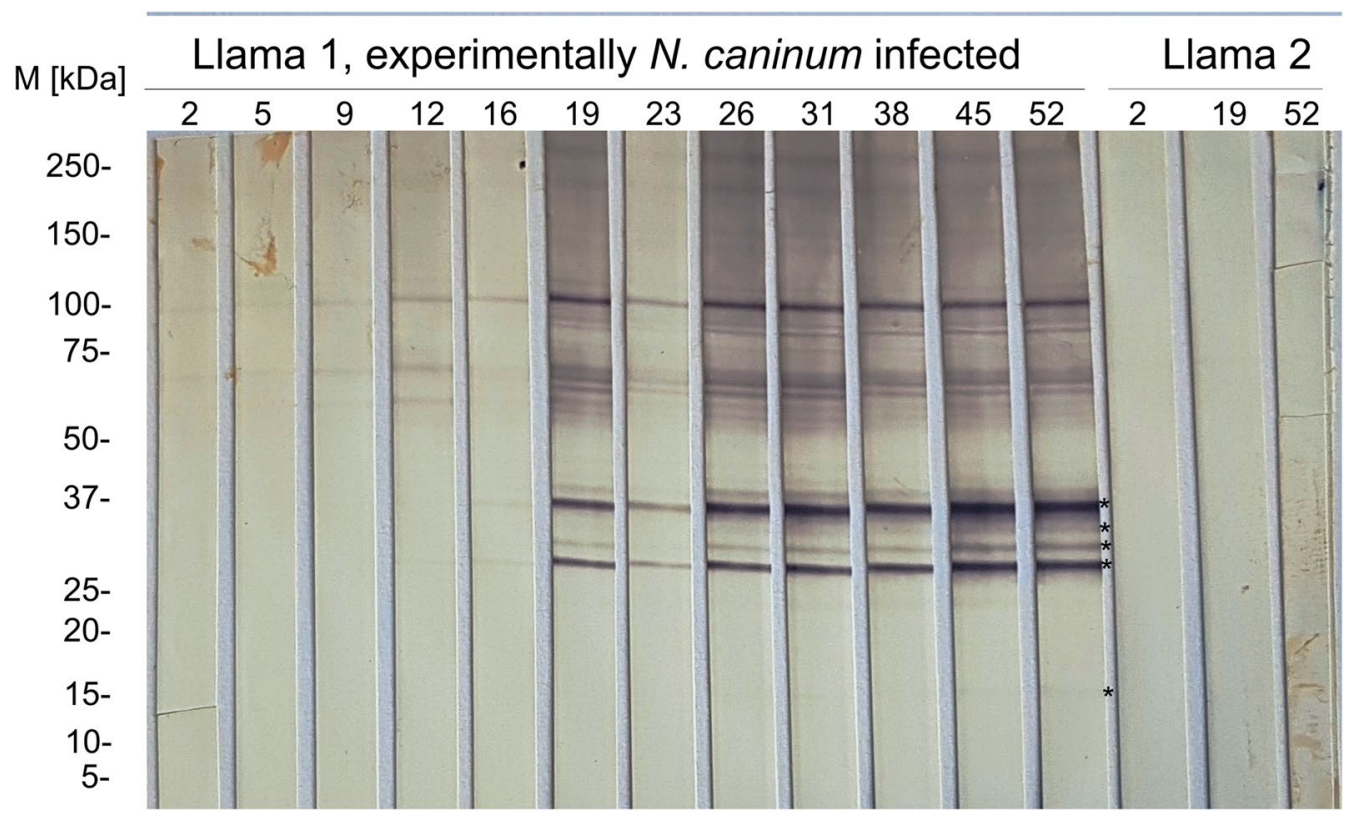

Fig. 5 Immunoblot results for antibodies against N. caninum on serum samples from a llama experimentally inoculated with $4.8 \times 10$ E6 cell culture-derived $N$. caninum tachyzoites (Llama 1) and from a seronegative control llama inoculated with $5 \times 10$ E 4 Vero cells (Llama 2). Abbreviations: M, marker; kDa, kilodaltons; 2-52 (indicated above), days post-inoculation (dpi). Bands corresponding to immunodominant N. caninum antigens (17, 29, 30, 33 and $37 \mathrm{kDa}$ ) are indicated with an asterisk. In Llama 1, reaction against the $29 \mathrm{kDa}$ antigen is observed at $12 \mathrm{dpi}$. From 16 to $52 \mathrm{dpi}$ also further immunodominant antigens are recognized. Samples recognizing two or more immunodominant antigens were considered positive. Llama 2 did not recognize any of the $N$. caninum immunodominant antigens during the observation period

\section{Questionnaire and risk factor analysis}

A total of 41 out of 132 (31.1\%) farms responded to the web-based questionnaire. These farms accounted for 189 out of the 571 (33\%) animals sampled in the survey. Twenty-two farms bred exclusively alpacas, 12 farms exclusively llamas and seven farms bred both species. Considering only the responding farms and the adapted ELISA cut-offs, the seroprevalences for $T$. gondii and $N$. caninum at the farm level were $100 \%(n=41 / 41)$ and $14.6 \%(n=6 / 41)$, respectively, and at the animal level $77.8 \%(n=147 / 189)$ and $5.8 \%(n=11 / 189)$, respectively. Regarding the SAC species, $75.8 \%(91 / 120)$ of the alpacas and $81.2 \%(56 / 69)$ of the llamas were seropositive for $T$. gondii and $6.7 \%(8 / 120)$ of the alpacas and $4.3 \%(3 / 69)$ of the llamas were seropositive for $N$. caninum.

All 41 responding farms bred Swiss SAC (born at the same farm or purchased from other Swiss farms). Only five farms (12.2\%) had purchased few animals abroad (i.e. Peru, Chile, USA, Australia, New Zealand and Germany). None of the tested animals from those five farms evidenced antibodies against $N$. caninum.

Thirty-five (85.4\%) of the farms reported presence of cats (one cat up to $>10$ cats) in the last two years, and kittens had been present in eight of these farms (22.9\%).
Either own or foreign/neighbouring cats had access to the pasture and stable in $34(97.1 \%)$ and $33(94.3 \%)$ of these farms, respectively. Own dogs (up to four dogs) were present in $22 / 41(56.7 \%)$ of the farms during the last two years and two $(9.1 \%)$ of those farms had puppies. Own dogs had access to the stable and pasture in 21 (95.4\%) of those 22 farms and foreign/neighbouring dogs were seen in at least 11 farms. Seven (17\%) of the farms had problems with rodents, and 34/41 (82.9\%) of the farms reported breeding other animal species (i.e. cattle, sheep, goats, equids, pigs, poultry, rabbits, quails, and fallow deer) besides SAC. Eleven (26.8\%) of the participating farms experienced abortions (up to five abortions) during the last two years and only one of the farms submitted the aborted foetuses for investigation, but no abortion cause could be detected.

Since all responding farms were $T$. gondii-seropositive (i.e. all 41 farms had at least one seropositive animal), no risk analysis for $T$. gondii at the farm level was possible. By generalized linear mixed modelling considering the individual serological status, the variable "age" (in months) was identified as putative risk factor for infection with T. gondii (Table 5) and female animals had a significantly increased risk of being $T$. gondii-seropositive (Table 5). 
Table 5 Fixed effects in generalized linear mixed models to determine potential risk factors for Toxoplasma gondiiseropositivity in Swiss South American camelids

\begin{tabular}{|c|c|c|c|c|}
\hline $\begin{array}{l}\text { Model } \\
\text { (AIC, } \\
\text { model fit) }\end{array}$ & Variable & $\begin{array}{l}\text { Odds ratio (95\% } \\
\text { Cl) }\end{array}$ & $z$-value & $P$-value \\
\hline \multirow[t]{2}{*}{$1(155.9)$} & Intercept & $\begin{array}{l}1.090(0.390- \\
3.070)\end{array}$ & 0.170 & 0.864644 \\
\hline & Age (months) & $\begin{array}{l}1.020(1.010- \\
1.040)\end{array}$ & 3.602 & $0.000316^{* * *}$ \\
\hline \multirow[t]{4}{*}{$2(153.4)$} & Intercept & $\begin{array}{l}0.607(0.209- \\
1.760)\end{array}$ & -0.919 & 0.358139 \\
\hline & Age & $\begin{array}{l}1.021(1.009- \\
1.030)\end{array}$ & 3.497 & $0.000471^{* * *}$ \\
\hline & Sex: male (ref.) & & & \\
\hline & Sex: female & $\begin{array}{l}2.924(1.111- \\
7.690)\end{array}$ & 2.174 & $0.029711^{*}$ \\
\hline \multirow[t]{4}{*}{$3(152.4)$} & Intercept & $\begin{array}{l}1.228(0.460- \\
3.278)\end{array}$ & 0.410 & 0.681820 \\
\hline & Age & $\begin{array}{l}1.024(1.011- \\
1.036)\end{array}$ & 3.707 & $0.000210^{* * *}$ \\
\hline & $\begin{array}{l}\text { Cat, past } 2 \text { years } \\
\text { (ref.) }\end{array}$ & & & \\
\hline & $\begin{array}{l}\text { No cat, past } 2 \\
\text { years }\end{array}$ & $\begin{array}{l}0.214(0.055- \\
0.828)\end{array}$ & -2.233 & $0.025530^{*}$ \\
\hline \multirow[t]{6}{*}{$4(149.3)$} & Intercept & $\begin{array}{l}0.692(0.255- \\
1.880)\end{array}$ & -0.722 & 0.470200 \\
\hline & Age & $\begin{array}{l}1.021(1.009- \\
1.033)\end{array}$ & 3.540 & $0.000400^{* * *}$ \\
\hline & Sex: male (ref.) & & & \\
\hline & Sex: female & $\begin{array}{l}2.941(1.164- \\
7.426)\end{array}$ & 2.282 & $0.022500^{*}$ \\
\hline & $\begin{array}{l}\text { Cat, past } 2 \text { years } \\
\text { (ref.) }\end{array}$ & & & \\
\hline & $\begin{array}{l}\text { No cat, past } 2 \\
\text { years }\end{array}$ & $\begin{array}{l}0.232(0.066- \\
0.809)\end{array}$ & -2.293 & $0.021900^{*}$ \\
\hline
\end{tabular}

Notes: Data were analysed by bivariable generalized linear mixed modelling including "Age" (months) as effect modifier and "Farm" as random effects variable in modelling T. gondii-seropositivity. The Akaike information criterion (AIC) was used to characterize the relative model quality

Abbreviation: ref., reference

${ }^{*} P \leq 0.05,{ }^{*} P \leq 0.01,{ }^{* *} P<0.001$

The variable "absence of cats in the farm during the last two years" was identified as a protective factor (Table 5).

None of the examined variables could be classified as a risk factor for $N$. caninum seropositivity, as the observed differences were not statistically significant. Moreover, modelling considering the infection status of the individual animals was not possible, because only 11 animals of six out of 41 farms that had answered the questionnaire tested positive, with four of these farms in which only a single animal tested positive. The relation of the putative risk factors with seropositivity to $N$. caninum at the farm level is displayed in Additional file 1: Table S1.

\section{Discussion}

The multi-species T. gondii and N. caninum ELISA kits used in this study (i.e. TOXO-MS and NCS-MS) were not previously validated for their use on SAC; therefore, the results obtained on SAC field samples were further confirmed by immunoblot, and control sera with known positive or negative serological status for $T$. gondii and $N$. caninum infections were included in the analyses. The immunoblot method was chosen as "gold standard for comparison" to estimate the cut-off of the kits for testing SAC and their relative diagnostic characteristics considering the optimized cut-offs. Subsequently, two further ELISA kits for detection of antibodies against $N$. caninum (i.e. NCC and NCS) were additionally evaluated on samples with known immunoblot results. With the optimized cut-offs, TOXO-MS, NCS-MS and NCC ELISAs had almost perfect agreement with immunoblot results (Table 4). Moreover, an almost perfect agreement was also observed between NCS-MS and NCC ELISAs (Table 4). On the other hand, a new version of the indirect ELISA (NCS), which uses an anti-ruminant conjugate, proved not to be suitable for testing SAC because it did not detect animals which tested seropositive for $N$. caninum antibodies both by immunoblot and by the two further tested $N$. caninum ELISAs. This kit differs from NCS-MS only in the used conjugate.

Almost nothing is known about the epidemiological situation or the clinical significance of T. gondii and $N$. caninum infections in SAC in Europe. Differences in the type of husbandry, possibility of contact with definitive hosts, geographical factors and/or occurrence of co-infections with other agents might influence the occurrence and/or clinical significance of these protozoan infections in Europe. Regarding prevalence studies on $T$. gondii infection, only few countries (i.e. Chile, Argentina, USA, Germany and Czech Republic) besides Peru (where several regional surveys have been carried out (Table 1)), investigated the occurrence of T. gondii antibodies in SAC. In Peru seroprevalences between 3.0 and $44.5 \%$ in alpacas, 8.6 and $44.2 \%$ in llamas and 2.6 and $5.5 \%$ in vicunas were reported (Table 1). In Argentina, a seroprevalence of $14.3 \%$ was reported in llamas from the North Western region by IFAT [37], and in Chile, prevalences of $7.2-11.8 \%$ in alpacas $[38,39]$ and $43.3 \%$ in llamas [39] were observed. In the USA, seroprevalences of 37.5 and $33.5 \%$ by MAT were observed in 16 alpacas [40] and 283 llamas [41], respectively. In Europe, antibodies against $T$. gondii were previously detected in a few SAC in Germany [30] and Czech Republic [42] by immunoblot, ELISA and/or IFAT. In this study, a general seroprevalence of $83.2 \%(475 / 571)$ in SAC living in Switzerland was revealed, which corresponded to seroprevalences of 
$82.3 \%(308 / 374)$ and $84.8 \%(167 / 197)$ in alpacas and llamas, respectively.

Seropositive animals derived from 131 out of 132 (99.2\%) sampled farms. Although due to differences in the serological techniques and cut-offs used in the different surveys, a direct comparison of some studies is not always possible, the here observed prevalences are much higher than those reported worldwide so far (Table 1). This is in agreement with the high (i.e. 80.7\%) T. gondii seroprevalence observed in Swiss ewes by P30-ELISA on meat juice [43]. The higher seroprevalence in SAC in Switzerland may be related to a more intensive management than in other geographical regions, enabling a closer contact with human premises and with domestic cats, which contaminate the pastures with their faeces. South American camelids often share grazing lands with sheep, being exposed to the same infection sources. Reported frequencies of domestic cats shedding T. gondii oocysts in Switzerland were between 0.4 [44] and $0.6 \%$ [45], which is probably $>10$ times higher to that of dogs shedding $N$. caninum oocysts. Moreover, the number of owned cats living in Switzerland is approximately three times higher than that of owned dogs (in year 2018: $1,634,000$ cats $v s 506,000$ dogs) [46], what can account for a higher environmental contamination with $T$. gondii oocysts.

Knowledge on the risk factors for infection is essential to make decisions on possible intervention measures. In ruminants, the main routes of infection with T. gondii include the ingestion of oocysts contaminating feed, water or the environment, and secondary, transplacental transmission [47]. In our study, the variables "age" and "female sex" were identified by multivariable statistical analysis as putative risk factors for $T$. gondii infection, while "absence of cats in the farm during the last two years" was suggested as a protective factor. The variable age was identified as a risk factor for T. gondii infection in numerous studies on different livestock species including small ruminants, cattle, equids, pigs and chicken [47]. In studies on SAC from Peru [30, 48-50], Chile [39] and Germany [30], it was observed that the seroprevalence of $T$. gondii infection increased with age, suggesting that most infections would occur postnatally. Accordingly, also in this study the variable age was estimated as a putative risk factor for infection (here also referred to as effect modifying variable in statistical analysis), and this can be explained, as older animals had more often the possibility of being exposed to T. gondii oocysts after birth than younger ones. While the variable "female sex" was suggested as putative risk factor for T. gondii seropositivity in few studies on small ruminants, pigs and equids; in most of the reported studies on livestock there was no statistical differences in the seroprevalence between both sexes [47]. It has to be considered that this apparent association might mask underlying factors such as differences in the way both sexes are reared more than to specific differences in susceptibility [47]. While in two studies from Peru, no statistical differences were observed in the seroprevalence of $T$. gondii infection between female and male alpacas $[49,50]$, in a further study it was found that female sex was a risk factor for acquiring toxoplasmosis in alpacas, but not in llamas [48]. The authors hypothesized that this could be due to differences in management, as llamas and male alpacas were pastured in cold, dry regions above $4000 \mathrm{~m}$ above sea level, and female alpacas were kept in lower, wet areas, what could account for a longer survival of $T$. gondii oocysts. Also in our study, female sex seemed to be a risk factor for T. gondii infection. In Switzerland, males are often held in "male herds", separated from the females; however, there are no big differences in the general management of both sexes that could account for a higher exposure to the parasite in females. While different experimental studies suggested a higher susceptibility of female mice and guinea pigs to infection with T. gondii [47], it is not known if this also applies to SAC.

Further, the variable "absence of cats in the farm during the last two years" was identified as a "protective factor" for $T$. gondii infection. Cats, as definitive hosts of $T$. gondii, are responsible for environmental contamination with oocysts shed with their faeces, which may survive for several months (usually $<2$ years) in the environment, and sporulated oocysts represent the main source of infection for ruminants [47]. Therefore, reporting an absence of cats on farms would account for lower chances of contamination of farmland, feed or water with oocysts.

The potential role of $T$. gondii-infected SAC meat as a source of infection for humans has been barely investigated and more studies are needed to better understand the correlation between seropositivity and presence of viable parasites in the tissues as well as to define the predilection sites of T. gondii in SAC. Recently, T. gondii was isolated from heart or muscle tissues from two out of six seropositive alpacas by bioassay in mice in the USA [40]. Meat from SAC represents an important food source for the Andean population in South America, where it is consumed as different local dishes not only cooked (e.g. as chupe, locro, pachamanca) but also raw in different preparations (e.g. as charqui, sausages or ceviche) [51]. In recent years, due to the higher protein and lower fat and cholesterol contents compared with meat from other livestock species, SAC meat has become an interesting kind of alternative red meat both for the local and international kitchen [52]. In Switzerland there are at least 15 listed providers of SAC meat and meat products [23]. SAC meat represents a gourmet dish, and it is often 
cooked only shortly at low temperature and consumed undercooked or raw as dried meat or sausages [23]. Given the high T. gondii seroprevalence observed, SAC meat might represent a potential infection source for humans if no treatment for parasite inactivation (e.g. cooking with core temperature $>67{ }^{\circ} \mathrm{C}$, freezing at $<-12{ }^{\circ} \mathrm{C}$ for $>2$ days) [1] is carried out.

Surveys based on the presence of N. caninum antibodies in blood sera from SAC have been scarcely performed worldwide and data from only few countries (i.e. Peru, Argentina, Australia, Germany and Czech Republic) are available (Table 2). Most of the studies were performed in Peru, mainly in the Andes region, and revealed seroprevalences of $0.3-42.4 \%$ in alpacas, $0-23.3 \%$ in llamas and $0-1 \%$ in vicunas (Vicugna vicugna) by various serological tests (Table 2). In Argentina, a study on 308 llamas from the North-Western region revealed a seroprevalence of $1 \%$ by IFAT [7]. Outside South America, only studies involving few animals were performed and the observed seroprevalences were low $(\leq 3 \%)[24,30,53]$. In Europe, only two small serological studies have been published to date [30, 42]. Neospora caninum infection could not be serologically detected in any of 32 SAC by immunoblot in Germany [30], and it was diagnosed in one out of 9 SAC in the Czech Republic by ELISA and IFAT [42]. Accordingly, also in the present study low seroprevalences of $N$. caninum infection were observed. While most serosurveys for $N$. caninum and T. gondii infections were performed at local or regional levels, this study aimed to reveal the epidemiological situation of these protozoan infections at a nationwide level. Antibodies against $N$. caninum were detected by ELISA and confirmed by immunoblot in $3.15 \%$ (18/571) of the tested animals and in $9.1 \%(12 / 132)$ of the farms (Fig. 1). Considering the SAC species, 3.5\% (13/374) of the alpacas and 2.5\% $(5 / 197)$ of the llamas tested in Switzerland were seropositive. Seropositive animals derived from 12 farms localized in seven Swiss cantons, showing a nationwide distribution of the parasite (Fig. 1). At least 12 out of the 18 seropositive animals derived from farms $(n=6)$ that reported not having imported animals. This suggests that the animals may get infected (horizontally or vertically) in Switzerland. For the remaining six animals, no information about a possible imported origin was known. In cattle, vertical transmission was considered the most important route of $N$. caninum infection, and it was shown that the parasite can persist in the herd during several generations even without further participation of the definitive host [54]. However, nothing is known about the efficiency of vertical transmission of $N$. caninum in SAC or about the meaning of horizontal transmission through the ingestion of sporulated oocysts shed by canids in these animal species. In Peru, no significant association was found between seropositivity to $N$. caninum in SAC and age [55, 56] or geographical region [57], suggesting that the infection might be mainly transmitted vertically [57]. Apart from some regional studies from Peru, in which higher seroprevalences of infection were reported (17.9-42.4 \% in alpacas and $18.4-23.3 \%$ in llamas) $[58,59]$, only low seroprevalences were observed in studies outside South America, suggesting that only few animals had contact with the parasite. In Europe, $N$. caninum oocysts were detected in the faeces of only few dogs [60-64], with prevalences $<0.05 \%$ [63], suggesting that the environmental contamination with oocysts might be low. Nevertheless, acute infections with $N$. caninum oocysts were considered responsible for epidemic abortion outbreaks in several cattle farms in the region, showing that under certain epidemiological situations focal contamination with $N$. caninum oocysts may occur $[65,66]$.

It is believed that $T$. gondii and $N$. caninum infections in SAC are generally subclinical, and accordingly, serologically positive animals in this study did not show any clinical signs. However, in recent years a case of generalized fatal toxoplasmosis was described in a 13-monthold llama in the USA. Due to the character of the lesions, which included gastritis and enteritis, it was assumed that the animal became infected through ingestion of oocysts contaminating feed or water [21]. Therefore, also potential clinical aspects of this infection should be considered. Besides, $T$. gondii and N. caninum infections are known causes of reproductive failure (i.e. abortion, stillbirths and perinatal mortality) in different domestic and wild ruminant species $[9,10,13,14,17,65]$ but only few studies were performed to elucidate their significance in SAC. In Peru, N. caninum DNA and associated histological lesions were detected in the brain from three out of 15 aborted SAC foetuses (i.e. 2/6 alpaca and 1/9 llama foetuses) from the Puno region [19]. Additionally, $N$. caninum infection was also detected by PCR or immunohistochemistry in further $14 / 50$ aborted SAC foetuses (i.e. 10/32 alpacas and 4/18 llamas) from the Central and South Andean regions of the Peruvian Highlands, of which eight foetuses also showed compatible lesions [18]. On the other hand, the role of T. gondii as cause of abortion in SAC has been subject of debate [57]. Two naïve llamas infected either experimentally or naturally with $T$. gondii during pregnancy remained clinically normal and delivered healthy, seronegative crias, suggesting that no transplacental transmission of the parasite occurred [67]. Later, T. gondii DNA was not detected in any of 15 [19] or 50 aborted foetuses from alpacas and llamas from Peru (while N. caninum was detected in some of the abortions), providing presumptive evidence that $T$. gondii is less important as a cause of abortion in SAC than $N$. caninum [18]. However, in the USA, toxoplasmosis was 
implicated as a cause of abortion in llamas, and antibodies against $T$. gondii were detected in foetal fluids from aborted foetuses [68]. Moreover, in recent years, T. gondii was confirmed as the cause of abortion in a near fullterm alpaca foetus [20]. Nevertheless, the real prevalence of N. caninum and T. gondii associated abortions in SAC might be often underestimated, as aborted foetuses from these animal species seem to be only rarely submitted to the laboratory for further diagnosis [24]. In our study, only one out of 11 farms which experienced abortions in SAC reported having sent abortion material for etiological investigation. Further studies to estimate the involvement of these parasites as cause of abortion in SAC in Switzerland are on-going.

\section{Conclusions}

One commercial ELISA kit for detection of antibodies against $T$. gondii and two kits for detection of $N$. caninum antibodies were assessed for their use in SAC and their cut-offs were optimized, showing almost perfect agreement with immunoblot results. One further commercial kit for the detection of antibodies against $N$. caninum in ruminants proved not to be useful for testing SAC. This nationwide cross-sectional study demonstrates, to our knowledge for the first time, the presence of antibodies against $T$. gondii and $N$. caninum in the Swiss SAC population and shed some light on the current epidemiological situation of these parasites, highlighting the occurrence of a low seroprevalence of $N$. caninum infection and a very high seroprevalence of $T$. gondii infection in llamas and alpacas in Switzerland, suggesting that SAC meat might represent an additional infection source for humans.

\section{Supplementary information}

Supplementary information accompanies this paper at https://doi. org/10.1186/s13071-020-04128-9.

Additional file 1: Table S1. Relation of putative risk factors with the serological status for N. caninum infection in South American camelids from 41 Swiss farms, considered at the farm level.

\section{Abbreviations}

SAC: South American camelids; ELISA: enzyme-linked immunosorbent assay; TOXO-MS: ID Screen ${ }^{\circledR}$ Toxoplasmosis Indirect ELISA kit ID.vet; NCS-MS: ID Screen ${ }^{\circledR}$ Neospora caninum Indirect Multi-species ELISA kit ID.vet; NCC: ID Screen ${ }^{\circledR}$ Neospora caninum Competition ELISA kit ID.vet; NCS: ID Screen ${ }^{\circledR}$ Neospora caninum Indirect ELISA kit ID.vet; iv: intravenously; dpi: days postinoculation; S/P\%: sample-to-positive ratio; S/N\%: competition percentage; OD: optical density; kDa: kilodaltons; v: volume; PBS: phosphate-buffered saline solution; ROC: receiver operating characteristics; AUC: area under the ROC curve; HO: null hypothesis; AIC: Akaike information criterion; IFAT: indirect fluorescent antibody test; FITC: fluorescein isothiocyanate conjugate; IHA: indirect hemagglutination; MAT: modified agglutination test; SE: standard error; Cl: confidence interval.

\section{Acknowledgements}

We would like to thank all the farmers that participated in the study, the technicians of the Institute of Parasitology, Bern: Ursula Kurath, Xuan-Lan Vu, Liliane Krähenbühl and Bernadette Merkle for their valuable technical assistance, and to Professor Gertraud Schüpbach (Veterinary Public Health Institute, Bern) for her help with the on-line survey.

\section{Authors' contributions}

WB and PZ designed and supervised the study. WB supervised and performed laboratory work, analysed the results and wrote the manuscript. ES performed the immunoassays, the web-based survey and contributed to the manuscript. GS and SK performed the statistical analysis. GS provided reference sera. FA and GMJ were involved in the sampling. PZ was involved in the sampling, results analysis and geoprocessing. All authors revised final manuscript. All authors read and approved the final manuscript.

\section{Funding}

This study received financial support from the "Verein zur Förderung der Forschung im Gesundheitssektor von Lamas und Alpakas e.V.,' Kronberg im Taunus, Germany.

\section{Availability of data and materials}

The datasets used and/or analysed during the current study are available from the corresponding author on reasonable request.

\section{Ethics approval and consent to participate}

The study was approved by the cantonal veterinary offices of the cantons involved, according to the regulations of the Swiss animal welfare legislation (Authorisation No. BE 5/17+). A written consent of the farmers to be involved in the study was obtained.

\section{Consent for publication}

Not applicable.

\section{Competing interests}

The authors declare that they have no competing interests.

\section{Author details}

${ }^{1}$ Institute of Parasitology, Vetsuisse-Faculty, University of Bern, Länggassstrasse 122, 3012 Bern, Switzerland. ${ }^{2}$ Clinic for Ruminants, Vetsuisse-Faculty, University of Bern, Bremgartenstrasse 109a, 3012 Bern, Switzerland. ${ }^{3}$ Friedrich-LoefflerInstitut, Federal Research Institute for Animal Health, Institute of Epidemiology, Südufer 10, 17493 Greifswald-Insel Riems, Germany. ${ }^{4}$ Veterinary Public Health Institute, Vetsuisse-Faculty, University of Bern, Schwarzenburgstrasse 161, 3097 Liebefeld, Switzerland. ${ }^{5}$ Centre for Fish and Wildlife Health (FIWI), Vetsuisse-Faculty, University of Bern, Längassstrasse 122, 3012 Bern, Switzerland.

Received: 26 January 2020 Accepted: 8 May 2020

Published online: 14 May 2020

\section{References}

1. Dubey JP. Toxoplasmosis of animals and humans. 2nd ed. Boca Raton: CRC Press; 2010

2. Dubey JP, Hemphill A, Calero-Bernal R, Schares G. Neosporosis in animals. Portland: CRC Press: 2017

3. Broglia A, Basso W. Parasites present in meat and viscera of land farmed animals. In: Devine C, Dikeman M, editors. Encyclopedia of meat sciences 2e, vol. 3. Oxford: Elsevier; 2014. p. 34-41.

4. Basso W, Edelhofer R, Zenker W, Möstl K, Kübber-Heiss A, Prosl H. Toxoplasmosis in Pallas' cats (Otocolobus manul) raised in captivity. Parasitology. 2005;130:293-9.

5. Basso W, Moré G, Quiroga MA, Pardini L, Bacigalupe D, Venturini L, et al. Isolation and molecular characterization of Toxoplasma gondii from captive slender-tailed meerkats (Suricata suricatta) with fatal toxoplasmosis in Argentina. Vet Parasitol. 2009;161:201-6.

6. Basso W, Venturini MC, Moré G, Quiroga A, Bacigalupe D, Unzaga JM, et al. Toxoplasmosis in captive Bennett's wallabies (Macropus rufogriseus) in Argentina. Vet Parasitol. 2007;144:157-61. 
7. Moré G, Pardini L, Basso W, Machuca M, Bacigalupe D, Villanueva MC, et al. Toxoplasmosis and genotyping of Toxoplasma gondii in Macropus rufus and Macropus giganteus in Argentina. Vet Parasitol. 2010;169:57-61.

8. Pardini L, Dellarupe A, Bacigalupe D, Quiroga MA, Moré G, Rambeaud $M$, et al. Isolation and molecular characterization of Toxoplasma gondii in a colony of captive black-capped squirrel monkeys (Saimiri boliviensis). Parasitol Int. 2015;64:587-90.

9. Chanton-Greutmann H, Thoma R, Corboz L, Borel N, Pospischil A. Abortions in small ruminants in Switzerland: Investigations during two lambing seasons (1996-1998) with special regard to Chlamydiae. Schweiz Arch Tierheilkd. 2002;144:483-92.

10. Dubey JP. Toxoplasmosis in sheep - the last 20 years. Vet Parasitol. 2009;163:1-14.

11. Kayser FH, Böttger EC, Deplazes P, Haller O, Roers A. Pocket textbook medical microbiology. 13th ed. Stuttgart: Thieme; 2014.

12. Maenz M, Schlüter D, Liesenfeld O, Schares G, Gross U, Pleyer U. Ocular toxoplasmosis past, present and new aspects of an old disease. Prog Retin Eye Res. 2014;39:77-106.

13. Campero LM, Gos ML, Moore DP, Regidor-Cerrillo J, Unzaga JM, Moré $G$, et al. Microsatellite pattern analysis of Neospora caninum from a naturally infected goat fetus. Vet Parasitol. 2018;255:58-60.

14. Unzaga JM, Moré G, Bacigalupe D, Rambeaud M, Pardini L, Dellarupe A, et al. Toxoplasma gondii and Neospora caninum infections in goat abortions from Argentina. Parasitol Int. 2014;63:865-7.

15. Porto WJN, Regidor-Cerrillo J, Kim PdCP, Benavides J, Silva ACdS, Horcajo P, et al. Experimental caprine neosporosis: the influence of gestational stage on the outcome of infection. Vet Res. 2016;47:29.

16. Sánchez-Sánchez R, Ferre I, Re M, Regidor-Cerrillo J, Blanco-Murcia J, Ferrer $L M$, et al. Influence of dose and route of administration on the outcome of infection with the virulent Neospora caninum isolate NcSpain7 in pregnant sheep at mid-gestation. Vet Res. 2018;49:42.

17. Basso W, Moré G, Quiroga MA, Balducchi D, Schares G, Venturini MC Neospora caninum is a cause of perinatal mortality in axis deer (Axis axis). Vet Parasitol. 2014;199:255-8.

18. Serrano-Martínez E, Collantes-Fernández E, Chávez-Velásquez A, Rodríguez-Bertos A, Casas-Astos E, Risco-Castillo V, et al. Evaluation of Neospora caninum and Toxoplasma gondii infections in alpaca (Vicugna pacos) and llama (Lama glama) aborted foetuses from Peru. Vet Parasitol. 2007;150:39-45.

19. Serrano-Martínez E, Collantes-Fernández E, Rodríguez-Bertos $A$, Casas-Astos E, Alvarez-García G, Chávez-Velásquez A, Ortega-Mora LM. Neospora species-associated abortion in alpacas (Vicugna pacos) and Ilamas (Lama glama). Vet Rec. 2004;155:748-9.

20. Dubey JP, Johnson JE, Hanson MA, Pierce V. Toxoplasmosis-associated abortion in an alpaca (Vicugna pacos) fetus. J. Zoo Wildlife Med. 2014;45:461-4

21. Dubey JP, Newell TK, Verma SK, Calero-Bernal R, Stevens EL. Toxoplasma gondii infection in llama (Lama glama): Acute visceral disseminated lesions, diagnosis, and development of tissue cysts. J Parasitol. 2014;100:288-94

22. Hengrave Burri I, Martig J, Sager H, Liesegang A, Meylan M. South American camelids in Switzerland. I. Population, management and health problems. Schweiz Arch Tierheilkd. 2005;147:325-34.

23. Neuweltkameliden Schweiz. 2020. http://www.nwks.ch/info. Accessed 18 Jan 2020.

24. King JS, Vaughan JL, Windsor PA. Serological evidence of Neospora caninum in alpacas from eastern Australia. Aust Vet J. 2015;93:259-61.

25. Erdin D. Livestock numbers in Switzerland. 2019. https://www.sbvusp.ch/de/agristat-aktuell-09-19-der-nutztierbestand-der-schweiz/. Accessed 1 Jan 2020

26. Franz S, Wittek T, Joachim A, Hinney B, Dadak AM. Llamas and alpacas in Europe: Endoparasites of the digestive tract and their pharmacotherapeutic control. Vet. J. 2015;204:255-62.

27. Deplazes P, Eckert J, Mathis A, Samson-Himmelstjerna GV, Zahner H. Parasitology in veterinary medicine. Wageningen: Wageningen Academic Publishers; 2016.

28. Wenker C, Hatt JM, Hertzberg H, Ossent P, Hänichen T, Brack A, Isenbügel E. Dikrozöliose bei Neuweltkameliden. Tierarztl Prax Ausg G Grosstiere Nutztiere. 1998;26:355-61.
29. Erdin D. Livestock numbers in Switzerland. 2017. https://www.sbv-usp.ch/ de/agristat-aktuell-09-17-der-nutztierbestand-der-schweiz/. Accessed 1 Jan 2020.

30. Wolf D, Schares G, Cardenas O, Huanca W, Cordero A, Bärwald A, et al. Detection of specific antibodies to Neospora caninum and Toxoplasma gondii in naturally infected alpacas (Lama pacos), llamas (Lama glama) and vicunas (Lama vicugna) from Peru and Germany. Vet Parasitol. 2005;130:81-7.

31. Kritzner S, Sager H, Blum J, Krebber R, Greif G, Gottstein B. An explorative study to assess the efficacy of toltrazuril-sulfone (ponazuril) in calves experimentally infected with Neospora caninum. Ann Clin Microbiol Antimicrob. 2002;1:4.

32. Staubli D, Nunez $S$, Sager H, Schares G, Gottstein B. Neospora caninum immunoblotting improves serodiagnosis of bovine neosporosis. Parasitol. Res. 2006;99:648-58.

33. R Foundation for Statistical Computing, Vienna, Austria. R software, version 3.5.3. http://www.R335.project.org. Accessed 20 Dec 2019.

34. Swets JA. Measuring the accuracy of diagnostic systems. Science. 1988;240:1285-93.

35. GraphPad Software. QuickCalcs. http://www.graphpad.com/quickcalcs/ kappa2. Accessed 24 Jan 2020.

36. Landis JR, Koch GG. The measurement of observer agreement for categorical data. Biometrics. 1977;33:159.

37. Moré G, Pardini L, Basso W, Marín R, Bacigalupe D, Auad G, et al. Seroprevalence of Neospora caninum, Toxoplasma gondii and Sarcocystis sp. in llamas (Lama glama) from Jujuy, Argentina. Vet Parasitol. 2008;155:158-60.

38. Gorman T, Arancibia JP, Lorca M, Hird D, Alcaino H. Seroprevalence of Toxoplasma gondii infection in sheep and alpacas (Lama pacos) in Chile. Prev Vet Med. 1999:40:143-9.

39. Patitucci AN, Pérez MJ, Barril G, Cárcamo CM, Muñoz A. Detección de anticuerpos séricos contra Toxoplasma gondii (Nicolle y Manceaux, 1909) en llamas (Lama glama Linneaus, 1758) y alpacas (Lama pacos Linneaus, 1758) de Chile. Arch Med Vet. 2006;38:179-82.

40. Dubey JP, Casey SJ, Zajac AM, Wildeus SA, Lindsay DS, Verma SK, et al. Isolation and genetic characterization of Toxoplasma gondii from alpaca (Vicugna pacos) and sheep (Ovis aries). Trop Anim Health Prod. 2014:46:1503-7.

41. Dubey JP, Rickard LG, Zimmerman GL, Mulrooney DM. Seroprevalence of Toxoplasma gondii in llamas (Lama glama) in the northwest USA. Vet Parasitol. 1992:44:295-8.

42. Bártová E, Kobédová K, Lamka J, Kotrba R, Vodička R, Sedlák K. Seroprevalence of Neospora caninum and Toxoplasma gondii in exotic ruminants and camelids in the Czech Republic. Parasitol Res. 2017;116:1925-9.

43. Berger-Schoch AE, Bernet D, Doherr MG, Gottstein B, Frey CF. Toxoplasma gondii in Switzerland: a serosurvey based on meat juice analysis of slaughtered pigs, wild boar, sheep and cattle. Zoonoses Public Health. 2011;58:472-8

44. Frey C, Berger-Schoch A, Herrmann D, Schares G, Müller N, Bernet D, et al. Occurrence of Toxoplasma gondii genotypes in muscle of sheep, cattle and pigs and in cat faeces in Switzerand. Schweiz Arch Tierheilkd. 2012;154:251-5.

45. Zottler E-M, Bieri M, Basso W, Schnyder M. Intestinal parasites and lungworms in stray, shelter and privately owned cats of Switzerland. Parasitol Int. 2019;69:75-81.

46. Schultz E. Domestic animals in Switzerland. 2019. https://de.statista.com/ themen/3748/haustiere-in-der-schweiz/. Accessed 5 Jan 2020.

47. Stelzer S, Basso W, Benavides Silván J, Ortega-Mora LM, Maksimov P, Gethmann J, et al. Toxoplasma gondii infection and toxoplasmosis in farm animals: risk factors and economic impact. Food and Waterborne Parasitol. 2019;15:e00037.

48. Gómez OF, Chávez-Velásquez A, Casas-Astos E, Serrano-Martínez E, Cárdenas O. Determinación de la seroprevalencia de toxoplasmosis en alpacas y llamas en la estación experimental INIA-Puno. Rev Inv Vet Perú. 2003:14:49-53.

49. Ramirez JR, Chávez-Velásquez A, Casas-Astos E, Rosadio-Alcantara R, Falcón PN. Seroprevalencia de Toxoplasma gondii en alpacas de comunidades de la provincia de Canchis, Cusco. Rev Inv Vet Perú. 2005:16:162-74.

50. De La Poma CE, Chávez-Velásquez A, Casas-Astos E, Falcón PN, Zárate RD. Seroprevalencia de Toxoplasma gondii en alpacas (Lama pacos) en una 
unidad de producción comercial de la Sierra Central del Perú. Rev Inv Vet Perú. 2008;19:43-8.

51. Avilés Esquivel DF, Montero M, Barros-Rodríguez M. South American camelids: products and sub-products used in the Andean region. AICA. 2018;11:30-8.

52. Polidori P, Renieri C, Antonini M, Lebboroni G. Llama meat nutritional properties. Italian J Animal Sci. 2007;6:857-8.

53. Cockcroft PD, Dornin LE, Lambert RC, Perry J, Reichel MP. Serological survey for antibodies against bovine viral diarrhoea virus and Neospora caninum in a population of South Australian alpacas (Vicugna pacos). Aust Vet J. 2015:93:476-8.

54. Moré G, Bacigalupe D, Basso W, Rambeaud M, Beltrame F, Ramirez B, et al. Frequency of horizontal and vertical transmission for Sarcocystis cruzi and Neospora caninum in dairy cattle. Vet Parasitol. 2009;155:51-4.

55. Sante R, Serrano-Martínez E. Neosporosis en alpacas de la provincia de Huaytará, Huancavelica, Perú. Rev Investig Vet Perú. 2018;29:1456.

56. Pilco M, Serrano-Martínez E. Neospora caninum en llamas de Huancavelica, Perú. Rev Investig Vet Perú. 2018;29:1449.

57. Chávez-Velásquez A, Aguado-Martínez A, Ortega-Mora LM, Casas-Astos E, Serrano-Martínez E, Casas-Velásquez G, et al. Toxoplasma gondii and Neospora caninum seroprevalences in domestic South American camelids of the Peruvian Andes. Trop Anim Health Prod. 2014:46:1141-7.

58. Chávez-Velásquez A, Serrano-Martínez E, Casas-Astos E, Ortega-Mora LM. Neospora caninum en camélidos sudamericanos peruanos. Rev Inv Vet Perú. 2002;13:92-3.

59. Chávez-Velásquez A, Alvarez-García G, Collantes-Fernández E, Casas-Astos E, Rosadio-Alcántara R, Serrano-Martínez E, Ortega-Mora LM. First report of Neospora caninum infection in adult alpacas (Vicugna pacos) and Ilamas (Lama glama). J Parasitol. 2004;90:864-6.

60. Basso W, Herrmann DC, Conraths FJ, Pantchev N, Vrhovec MG, Schares G. First isolation of Neospora caninum from the faeces of a dog from Portugal. Vet Parasitol. 2009;159:162-6.

61. Basso W, Schares S, Bärwald A, Herrmann DC, Conraths FJ, Pantchev N, et al. Molecular comparison of Neospora caninum oocyst isolates from naturally infected dogs with cell culture-derived tachyzoites of the same isolates using nested polymerase chain reaction to amplify microsatellite markers. Vet Parasitol. 2009;160:43-50.

62. Slapeta JR, Modrý D, Kyselová I, Horejs R, Lukes J, Koudela B. Dog shedding oocysts of Neospora caninum: PCR diagnosis and molecular phylogenetic approach. Vet Parasitol. 2002;109:157-67.

63. Schares G, Pantchev N, Barutzki D, Heydorn AO, Bauer C, Conraths FJ. Oocysts of Neospora caninum, Hammondia heydorni, Toxoplasma gondii and Hammondia hammondi in faeces collected from dogs in Germany. Int J Parasitol. 2005;35:1525-37.
64. Perrucci S, Gavazza A, Rocchigiani G, Nardoni S, Zbriger A, Lubas G, Mancianti F. Neospora caninum oocyst shedding in a naturally infected dog from Italy. Vet Parasitol Reg Stud Rep. 2017;8:10-2.

65. Basso W, Schares S, Minke L, Bärwald A, Maksimov A, Peters M, et al. Microsatellite typing and avidity analysis suggest a common source of infection in herds with epidemic Neospora caninum-associated bovine abortion. Vet Parasitol. 2010;173:24-31.

66. Sager H, Hüssy D, Kuffer A, Schreve F, Gottstein B. Mise en evidence d'un cas de "abortion storm" (transmission transplacentaire exogène de Neospora caninum) dans une exploitation de vaches laitières: une première en Suisse. Schweiz Arch Tierheilkd. 2005;147:113-20.

67. Jarvinen JA, Dubey JP, Althouse GC. Clinical and serologic evaluation of two llamas (Lama glama) infected with Toxoplasma gondii during gestation. J Parasitol. 1999;85:142-4.

68. Cheney JM, Allen GT. Parasitism in Llamas. Vet Clin N Am Food Anim Pract. 1989;5:217-25.

69. Chávez-Velásquez A, Alvarez-García G, Gómez-Bautista M, Casas-Astos E, Serrano-Martínez E, Ortega-Mora LM. Toxoplasma gondii infection in adult llamas (Lama glama) and vicunas (Vicugna vicugna) in the Peruvian Andean region. Vet Parasitol. 2005;130:93-7.

70. De La Cruz CH, Chávez-Velásquez A, Casas-Astos E, Li EO. Seroprevalencia de Toxoplasma gondii en alpacas hembras de la Sais Pachacútec, Sierra Central del Peru. Rev Inv Vet Perú. 2011;22:35-8.

71. Loayza ME, Casas-Astos E, Chávez-Velásquez A, Coronado SL, Venturini de Arana C. Evaluación de Toxoplasma gondii en llamas hembras de dos comunidades campesinas de la región de Puno. Rev Inv Vet Perú. 2011:22:239-43.

72. Casas-Velásquez G, Chávez-Velásquez A, Casas-Astos E, Leyva W, Alvarado SA, Serrano-Martínez E, et al. Presencia de Neospora caninum en llamas de una empresa ganadera de la Sierra Central. Rev Inv Vet Perú. 2006;17:8-13.

73. Risco-Castillo V, Wheeler JC, Rosadio R, García-Peña FJ, Arnaiz-Seco I, Hoces $D$, et al. Health impact evaluation of alternative management systems in vicuña (Vicugna vicugna mensalis) populations in Peru. Trop Anim Health Prod. 2014;46:641-6.

\section{Publisher's Note}

Springer Nature remains neutral with regard to jurisdictional claims in published maps and institutional affiliations.

Ready to submit your research? Choose BMC and benefit from:

- fast, convenient online submission

- thorough peer review by experienced researchers in your field

- rapid publication on acceptance

- support for research data, including large and complex data types

- gold Open Access which fosters wider collaboration and increased citations

- maximum visibility for your research: over $100 \mathrm{M}$ website views per year

At BMC, research is always in progress.

Learn more biomedcentral.com/submissions 